\title{
AN ARCHAEOLOGY OF THE CONTEMPORARY PAST: EXCAVATIONS IN THE GROZĀVEŞTI PARK, BUCHAREST
}

\author{
Sorin OANŢä-MARGHITU
}

\section{O ARHEOLOGIE A TRECUTULUI APROPIAT: SĀPĀTURI ÎN PARCUL GROZĀVEŞTI, BUCUREȘTI}

Articolul prezintă rezultatele săpăturilor arheologice preventive din Bucureşti - Parcul Grozăveşti desfăşurate în 2005 şi 2007. Parcul a fost amenajat pe o movilă formată prin depunerea în anii 1980 de resturi de materiale de construcţii, pământ, deşeuri și diferite obiecte. Este discutat raportul dintre discursurile modemităţii care au structurat peisajul urban de-a lungul timpului şi discursul arheologic. Arheologia trecutului apropiat construieşte durata timpului prin imaginile dinamice ale unui prezent amestec de diferite timpuri, materialități cu biografii și vârste diferite, cu distrugeri şi refaceri. Se referă la modul în care memoria este manipulată prin producerea spaţiului şi dezvăluie starea nudă a modemităţii, de proiect veşnic nefinalizat. Arheologia spune o poveste a diferitelor ,clase-obiect”, a căror istorie a fost scrisă întotdeauna de altcineva.

CUVINTE CHEIE: arheologia trecutului apropiat, București, funcţionalism, comunism, ideologie. KEY WORDS: archaeology of the contemporary past, Bucharest, functionalism, communism, ideology.

"We are obstinately looking for material traces of $1,000,2,000,3,000$ years ago. This high archaeological spirit should watch also certain more immediate actions. The past of yesterday is also past, hardly past present and continuity; by destroying its materiality we are moving it into prehistory."

BUCHAREST-VASILE MILEA BOULEVARD NO. 5D, 5E AND 5F (GROZĂVEŞTI PARK)

At this "address" (between an OMV gas station, a fire station, the fence of the Cotroceni Water Plant and the pedestrian underpass connecting the Politehnica metro station to the buildings of the Polytechnic University) the Grozăveşti Park is still to be found - the only green area to break the monotony of the rows of buildings erected during communism and after December 1989. It was built on a land which from the boulevard looks like a hill brow (PI. 5/2), a part of a prolongation raised from the tall right terrace of the Dâmbovita river at the border between the river meadow and the Grozăveşti and Cotroceni hills. When looking at the hill slope from the gas station

${ }^{1}$ Sorescu 1985, 156-157. forecourt (PI. 5/1) one would never know that this is in fact an artificial hill, a lawncovered waste dump. In 2005 and 2007, when a team of the National Museum of Romanian History conducted here preventive excavations, the landscape (PI. 6), fragmented by a few paved paths and a hardly visible flowerbed among the tall grass, was a contradictory one, bearing the vague aspect of a park where the image of a clean and pleasant looking lawn-covered area met vacant land, trees surrounded at times by weeds and garbage dumps. We took into consideration the fact that in the immediate vicinity there is the Cotroceni complex, built at the end of the $17^{\text {th }}$ century $^{2}$. Also, the rescue excavations ${ }^{3}$ conducted around the complex, as well as on the Grozăvești Hill (the land on which the Polytechnic Institute buildings were erected) and at Cotroceni-Leu, Grozăveşti Road, the Grozăvești pumping station (near the power plant), have documented several

\footnotetext{
${ }^{2}$ Ionescu 1902, 32-173; Iorga 1939, 99; Stoicescu 1961, 47-50, 188-192; Cantacuzino 1968; Ciho et alii 1993, 22; Marsillac 1999, 153-154; Ştefánescu, Lazăr 2004.

${ }^{3}$ Panait 1969; Ștefánescu 1981; Ciho et alii 1993, 15; Poll, Mănucu-Adameșteanu 1997, 25; Ştefánescu, Lazăr 2004; Hanganu, Negru 2005.
} 
findings dating from the Neolithic, Bronze Age, the $9^{\text {th }}-11^{\text {th }}$ and $16^{\text {th }}-19^{\text {th }}$ centuries.

\section{GROZĂVEŞTI-COTROCENI: THE}

MATERIALITY OF TIME

The recently inaugurated Basarab Overpass and the two metro stations (Politehnica and Grozăvești) provide an organic connection with the rest of the city, but at the same time also consecrate the transit feature of the area. The pace of the city hides the natural configuration, as the previously firm limit between the plateau, the meadow and the river is blurred by the smooth slopes of the embankments of the two roads: the Vasile Milea Boulevard and the Grozăveşti Road. Together with the Iuliu Maniu Boulevard (on the Cotroceni plateau) and the Independenţei Causeway (on the bank of the river Dâmbovita), they are the main elements structuring the urban texture. Especially around the Dâmboviţa river, towards the Polytechnic University, they align tall buildings of metal and glass, a stylistic mark of the post-Revolution period. Beyond this front, through a few side streets (Plt. Ion Topor, Lt. Ştefan Marinescu, Economu Atanase Stoicescu), one enters an entirely different area, a mixture of houses and villas hidden and overwhelmed by the new buildings. Several periods of time merge within the same area.

"Time is immaterial only in appearance. On the contrary, both time and space are made of a solid matter on which every passage leaves traces and marks. The vaults of time are fringed by bushes on which pieces of our days and our youth are left hanging."4

Within historical and archaeological writings there is an aspiration to seek sequences of static, photographic images of the past, which are characteristic for the ambience of certain periods of time - a narration unfolding over linear time about standstills frozen in the distance. The church of Cărămidarii de Sus, a trace of the $19^{\text {th }}$ century neighbourhood, together with

\footnotetext{
${ }^{4}$ Voronca $1973,71$.
}

military and industrial images ${ }^{5}$, and homes grouped around the Royal Palace, were completed during the communist period by apartment buildings erected on the Iuliu Maniu Boulevard (formerly the Armata Poporului Boulevard) and by an academic touch, emphasized in its post-1989 private (privatized) version.

The new buildings (Ayash Center, Global Business Center, the Ecological University, the Artifex University, the OMV gas station) blend the ages of the other buildings into an "old time" which, from the point of view of people's biographies, can be attributed to the communist period. In fact, many buildings represent in this area the very beginning of the modernization of Bucharest during the late $19^{\text {th }}$ century and early $20^{\text {th }}$ century, and their own biography is marked by reconstructions, consolidations, additions: the buildings and tanks of the water plant ${ }^{6}$, the hydraulic power plant (CET Grozăveşti) $^{7}$, the Pirotehnia Armatei/ Military Pyrotechnics (concealed under the current name PUMAC) ${ }^{8}$. Also, the Dâmboviţa riverbed was systematized and regularized at the end of the $19^{\text {th }}$ century ${ }^{9}$ at the same time as the construction of the two roads "with trees on each side and with sewerage" 10 . The area is also connected to the beginnings of the electric tram in Bucharest and to the building of the first boulevards $^{11}$. A great part of the biography of the Elena Doamna Asylum (established in 1862) ${ }^{12}$ and of the Botanical Garden (set up in 1887$)^{13}$, took place around the Ştefan

\footnotetext{
5 Ionescu 1902; Popescu-Lumină 2007, 150-153; Chelcea 2008, 103-104, 176-190.

${ }^{6}$ Ionescu 1969, 89; Târnă 1997; Pănoiu 2011, 140 142.

7 Ionescu 1902, 390-391; Georgescu et alii 1965, 274, 299; Giurescu 1979, 139; Silvestru 1997, 147; Damé 2007, 213-214, 294.

${ }^{8}$ Ionescu 1902, 311-323; Marsillac 1999, 256-257; Chelcea 2008, 189.

${ }^{9}$ Caranfil et alii 1936, 197-203; Pănoiu 2011, $130-$ 139; Lascu 2011, 19-22.

${ }^{10}$ Licherdopol $1889,143$.

" Lascu 2011, 23-30, 138-140.

12 Slavici 1884; Borş 1932; Harasim 1992, 168; Marsillac 1999, 253-255; Damé 2007, 403-404.

${ }^{13}$ Ionescu 1902, 191-195, 398-424; Giurescu 1966, 397; Toma 2001, 136; Popescu-Lumină 2007, 359362; Pănoiu 2011, 164-165.
} 
Gheorghiu Academy, the APACA factory and the communist apartment buildings. During the long communist period, the Cotroceni Palace was given various functions, which erased from many people's memory the previous significance connecting it to the royal family. With the exception of the Vasile Milea Boulevard (built in 1986 as an extension of the former Ho Chi Minh Boulevard to the Grozăveşti Bridge), the other access roads to the area were built during the same modemization period: the Iuliu Maniu Boulevard (formerly Armata Poporului, formerly I.G. Duca, formerly Bolintin Road), the Cotroceni Road ${ }^{14}$, the Grozăvești Road, and the Geniului Boulevard. At present, they align new buildings, of standardized monumentality that refuses attention, and buildings belonging to a homogenized "old time": commercial billboard support, sometimes democratically assigned to be demolished or repurposed. The archaeology of the contemporary past dismantles the mechanism by which memory is manipulated through the production of space.

On the Global Business Center building, which, from the edge of the plateau, dominates the area towards the Dâmboviţa river, several names of companies were displayed successively from 2005 to the present moment: Connex, Vodafone, IBM. In the vicinity, on the plateau, through the tall weeds growing on the PUMAC factory premises, one can find scattered around pieces of the brick and mortar walls of the Military Pyrotechnics building, erected in 1873 and recently demolished, as well as the tile flooring of a former slot machine pub opened after 1989. On the other side of the Iuliu Maniu Boulevard, the buildings of the Faculty of Electronics, Telecommunications and Information Technology (the former Ştefan Gheorghiu Academy building) were erected in 1975 on the spot where the headquarters of a military engineering unit used to be during the interwar period ${ }^{15}$. The monument in front of the faculty, dedicated to Panait

\footnotetext{
${ }^{14}$ Popescu-Lumină 2007, 149-150.

${ }^{15}$ Stoica et alii $1999,148,183$.
}

Donici, commander of the first engineering battalion between 1859-1862, refers to the now lost military significance of the area. The palace built by Constantin Serban in 1680 , the Ypsilantis's pavilion, built in 1780 , and part of the fortification walls of the Cotroceni Palace were demolished between 1893-1896 to build the new palace designed by architect Paul Gottereau ${ }^{16}$. In the same location, the church of the Cotroceni Monastery, founded at the end of the $17^{\text {th }}$ century and demolished in 1984 , was rebuilt in 2004. The landscape is permanently undergoing change, making it impossible to pinpoint a still instance, a frozen image of specific moments. Urban space homogenizes and manipulates times, blends the biographies of places into a present time of functionality and people's subjective time, vaguely oriented towards the future. The archaeology of contemporary past builds the length and depth of time through dynamic images of a present time where various times meet materialities of different biographies and ages, with their destructions and rebuilds ${ }^{17}$.

\section{GROZĂVESTTI-COTROCENI: A PREHISTORY}

A few published texts and a few illustrated sherds represent the prehistoric past (Neolithic and Bronze Age) of various places in the area: the Military Pyrotechnics ${ }^{18}$, the Cotroceni Church and Palace area ${ }^{19}$, behind the Electrical Machines Plant ${ }^{20}$ and on the Grozăvești Hill $^{21}$. The names of these sites only enrich the catalogues of finds of "cultures" monographs ${ }^{22}$; on a map, they acquire a strange materiality, as illusory nodes of a vague network of sites in the Bucharest sector of the Dâmboviţa river. The Dridu ceramics from an early medieval settlement on the Grozăveşti Hill were only useful for dating it to the $9^{\text {th }}-11^{\text {th }}$ centuries. This

\footnotetext{
${ }^{16}$ Ionescu 1902, 174-195; Damé 2007, 403-404.

17 On the relationship between archaeology and memory, see Olivier 2008.

${ }^{18}$ Rosetti 1929, 7.

${ }^{19}$ Ciho et alii 1993, 14-15.

${ }^{20}$ Panait 2005, 250.

${ }^{21}$ Panait 1969, 36-39; Ștefănescu 1981, 275-278.

${ }^{22}$ Schuster 1997, 176 nr. 27-28; Leahu 2003, 27.
} 
discourse style translates social practices of the past - the action of digging pits, depositing items that have concluded their biographies, particular moments of the biography of constructions, the materiality of the long duration of debris and ruins into the scientific time, linear and segmented, tiered, of the sequence of various ages, cultures, stages: Neolithic, Glina, Tei, Dridu. This time can be compressed, if necessary, to give a meaning to historical scenarios of interpretation of the past, or expanded in order for the various "layers" defined by archaeologists to acquire chronological relevance.

\section{THE GROZĀVEŞTI PARK: RESEARCH}

\section{METHODS}

In 2005, before beginning the excavation, surface research established that the park paths were probably cast in 1989 (Pl. 6). None of the found materials were older than contemporary. Considering the results of the first prospections and the geoelectric measurements (see Annex) conducted in the Western side of the park we used a backhoe to excavate 29 trenches (PI. 1); their location, density, orientation and size depended on the land configuration, the routes of the paths, the presence and density of groups of trees (many of which were removed during our research by Public Domain Administration workers, to be relocated to a new residential district). The excavated depth $(3.5-4 \mathrm{~m})$ depended on the technical limitations of the machinery. Subsequently we also took into consideration the fact that the walls of the soundings excavated to that depth collapsed due to the instability of the filling. Information was recorded by notes in the field journal and by digital photography of the soundings and their profiles. We also photographed on site the items found in various trenches.
GROZĀVEŞTI, COTROCENI, LUPEȘTI: AN OBJECT-CLASS

On what is nowadays the territory of Bucharest, among other villages ${ }^{23}$, medieval documents also mentioned, starting with the $15^{\text {th }}-16^{\text {th }}$ centuries, Grozăveşti, Cotroceni, and Lupeşti ${ }^{24}$. The Cotroceni estate was described as follows in a charter issued in 1660 by the ruler Gheorghe Ghica, granting the estate to Serban Cantacuzino for his services:

"the whole village with all its land and all its income, from the field and the forest and the river and the village households, of everywhere, as much as it may amount to, and with as many people as dwell in this village, and with the vineyards and the mills and the orchards." 25

Two decades later, the ruler Serban Cantacuzino donated the estate to the Cotroceni monastery:

"the whole village with all its land and all its income, from the field and the forest and the Dâmboviţa river, with its millruns and the mills on the river, and with the vineyards, orchards and the village households, of everywhere and throughout the land, by the old borders and landmarks." 26

In 1672, Şerban Cantacuzino bought from Ianaki Logofătul the part of the estate at Lower Cotroceni, located immediately to the East of our research area, "the field, the forest with millruns and a broken mill and the orchards and vineyards that belonged to the village" ${ }^{27}$, and later donated it to the Cotroceni Monastery.

\footnotetext{
23 Giurescu 1966, 255-259; Panait 1978, 170; Giurescu 1979, 209-214; Panait, Ştefănescu 1981; Ghinea 1992; Panait 2005.

${ }^{24}$ Ionescu 1902; Giurescu 1966, 255; 255 fig. 174; Panait 1969, 34-39; Giurescu 1979, 210; Ciho et alii 1993, 13; Istoria Cotrocenilor 2001; Panait 2005, 247; Velescu 2007.

${ }^{25}$ Istoria Cotrocenilor 2001, 18.

${ }^{26}$ Istoria Cotrocenilor 2001, 28.

${ }^{27}$ Ionescu 1902, 14.
} 
The village documented on the Grozăvești Hill by the 1966-1970 rescue excavations included several pit-dwellings and "bread baking ovens" scattered around a cemetery of which 12 graves were investigated $^{28}$. Approximately $300 \mathrm{~m}$ away, towards the crest of the hill, there were other pit-dwellings and another cemetery. It was hypothesized that at a certain moment during the $16^{\text {th }}$ century the village moved up, on the high terrace, due to repeated floods of the Dâmbovița river ${ }^{29}$. Grain storage pits were found in the vicinity of the Culture House on Grozăveşti Road ${ }^{30}$. Also, rescue excavations conducted in the '1960s on the Eastern side of the Spirii Hill (Dealul Spirii) provided the fragmented image of a village (identified as Lupeşti) from the $14^{\text {th }}-16^{\text {th }}$ century, of which only one pit-dwelling was researched; its filling revealed animal bones and pottery fragments. A small group of seven inhumation graves and a "mass grave" found on the Western side of the headland probably belonged to this village. There is also mention of a few "grain storage pits" outside the cemetery ${ }^{31}$.

Knowledge of the medieval past of Cotroceni and Grozăvești is mediated by texts, charters by which estates were granted, confirmed, purchased or recovered. Documents mirror facts but also create their own reality, constructing a landscape that was important for the estates consisting of villages, people, orchards, vineyards, rivers, forests, mills. Historians have repeated in their work the same discourse of documents, and the only debated process was that of enslaving free villages and dividing up common property ${ }^{32}$. Archaeology does more than just complement written information, despite the fact that the excavation reports were limited to identifying on site villages mentioned in medieval documents and the found items were only important as regards their function in establishing a chronology. Archaeology tells the story of the

\footnotetext{
${ }^{28}$ Panait 1967, 13; Panait 1969, 36-39; Panait 1992b, 79; Ştefãnescu, Lazăr 2004, 16; Panait 2005.

${ }^{29}$ Stefănescu 1981, 275-278.

${ }^{30}$ Ştefănescu, Lazăr 2004, 14; Panait 2005.

${ }^{31}$ Panait 1969, 34-36.

${ }^{32}$ Velescu 2007.
}

underground architecture of pit-dwellings and ovens, of grains stored in pits, of the practice of discarding food waste and disused vessels in abandoned pit-dwellings, of incorporating the world of the dead into domestic life. "[L]es classes dominées ne parlent pas, elles sont parlées" ${ }^{\text {"33 }}$ : there is an ethical side to archaeology when it speaks of "object classes" whose history has always been written by others.

\section{COTROCENI-GROZĀVEŞTI: THE EYELASH OF} BUCHAREST

The orchards, vineyards and mills mentioned in medieval documents also depict the landscape of the CotroceniGrozăveşti area in the $18^{\text {th }}$ century. To these touches we must add the Vlăsia Forest, in the middle of which Constantin Serban built between 1679-1681 the Cotroceni Monastery with its church, royal houses, abbot's houses, monks' cells and other annexes $^{34}$. The first Bucharest maps dating from the end of the century ${ }^{35}$ recorded the monastery's position outside the city, on the terrace plateau on the right bank of the Dâmboviţa river, while the river meadow was occupied by gardens. In 1759, for Kesarie Dapontes the Cotroceni Monastery was an element of an anthropomorphic image of Bucharest: "Bucharest has the very famous monasteries of Mihai Vodă and Radu Vodă for eyebrows, the Cotroceni and Văcăreşti for eyelashes and for a nose Plumbuita, the famous cloister of the Xeropotam" " Cotroceni as an "eyelash" of Bucharest suggests the ambiguity of the perception of this area, a monastery in a natural environment - still preserved during the $19^{\text {th }}$ century, as revealed by prints and descriptions dating from that time ${ }^{37}-$, half an hour away from the city, but at the same time an important religious and political

\footnotetext{
${ }^{33}$ Bourdieu 1977, 4.

${ }^{34}$ Ionescu 1902, 35-36; Iorga 1939, 99; Stoicescu 1961, 188-192; Cantacuzino 1968; Ciho et alii 1993, 22; Ştefănescu, Lazăr 2004.

35 Florescu 1935; Stoica et alii 1999, 119; 131; Pănoiu 2011, 26-27.

${ }^{36}$ Ionnescu-Gion 1899, 82.

37 Macovei, Varga 1993; Ciho et alii 1993, 36; Harasim 1993, 21; Marsillac 1999, 155-157.
} 
center connected to Bucharest. The image of Bucharest itself is marked by this ambiguity of the relationship between the very city, developed in the Dâmboviţa river meadow, on the left bank, around the Royal Court, bordered to the West, at the beginning of the $18^{\text {th }}$ century, by the Lupessti village on the Spirii Hill ${ }^{38}$ and the hills on the right river bank (Mihai Vodă, Mitropoliei, Radu Vodă, Lupeştilor, Cotrocenilor), a church erected on each of them. On these hills, wealthy city dwellers and monasteries administered their orchards, vineyards, crops. Monasteries also owned the mills on the Dâmboviţa river ${ }^{39}$. The river, "in the northern Grozăvești plain", as described by Dr. Constantin Caracas in a paper written between 1820-1828 and printed in Greek in 1830, "provides an enjoyable view when it gushes roaring towards the mills" ${ }^{40}$. The metaphor of Cotroceni as Bucharest's eyelash is a part of the idealised image of a "natural city", designating in fact a sort of functional spatialization and, moreover, a certain lifestyle characteristic to wealthy townspeople.

\section{COTROCENI-GROZǍVEŞTI: THE}

\section{CONCENTRIC CIRCLES METAPHOR}

At the beginning of the $20^{\text {th }}$ century, F. Damé noted that this lifestyle had disappeared about three decades before, at the same time as the vineyards that covered the Cotroceni Hill all the way to Vitan, through the Spirii Hill and through Filaret ${ }^{41}$. Also, the meadow gradually turned its natural scenery, dominated by the Dâmboviţa river and its mills, by spring and autumn floods when water would often reach the Cotroceni $\mathrm{Hill}^{42}$, into a suburban landscape. Some of the still visible ruins belonged, according to G.M. Ionescu, to

\footnotetext{
${ }^{38}$ Panait 1992a, 47.

39 Ionnescu-Gion 1899, 241, 301-306; Giurescu 1973, 144-145; Panait 1992a, 49.

${ }^{40}$ Serban 1978, 244.

${ }^{41}$ Damé 2007, 91.

42 Muşeţeanu 1935, 11-13; Bilciurescu 2003, 41; Damé 2007, 205.
}

mills that had been deactivated in $1865^{43}$ (together with all the rest, with the dams and bridges on the Dâmbovita) in order to prevent floods, a measure that preceded the correction of the river route ${ }^{44}$. The name Cărămidarii de Sus replaced the historical toponym Lupeşti and was later extended (partly due to a document dated 1814, which ruled that all brickmakers cărămidari - should move outside Bucharest) to cover the Lower Cotroceni and the Grozăveşti ${ }^{45}$. The memory of this suburb is nowadays preserved by the name of a church near the Grozăveşti Bridge built in 1805 and rebuilt several times ${ }^{46}$ and by the name of a street on the Western border of the premises of the faculties area in the Politehnica complex ${ }^{47}$. Grozăvești and Cotroceni are thus an ambiguous suburb as regards the function of various locations, an area that juxtaposed during the modern age the ruler's (and later on the king's) residence, warehouses, factories, an asylum, military headquarters, and a botanical garden. The same area hosted the vegetable gardens mentioned in passing in 1861 by Nicolae Filimon ${ }^{48}$ and the solemnity of military ceremonies during which new flags were distributed, as well as the celebration of Prince Cuza's name day in 1863, in the proximity of suburban houses and vineyard plots ${ }^{49}$. In 1907 , Grozăveşti, the suburb that the painter Ştefan Luchian moved to, had the appearance of a village:

"Ropes and bridles hanging outside, the crate of coarse salt by the door, and especially the white lime wood pole standing in front of the 'Yellow Inn' topped with a handful of curled wood shavings

\footnotetext{
${ }^{43}$ [onescu 1902, 363; see also Popescu-Lumină 2007, 151 .

${ }^{44}$ Ionnescu-Gion 1899, 241, 301-306; Georgescu et alii 1965, 299; Duţu 1967; Damé 2007, 209-210.

${ }_{45}$ Ionescu 1902, 107, pl. II; Muşeţeanu 1935, 5, 11 14; Popescu-Lumină 2007, 148, 156; Giurescu 1966, $258 ; 1979,213$.

46 Ionescu 1902, 552-557; Muşeteanu 1935; Stoicescu 1961, 181-182; Giurescu 1979, 213.

${ }^{47}$ Stoica et alii $1999,197$.

${ }^{48}$ Filimon 2005, 1054.

${ }^{49}$ Cotroceni 1867.
} 
ruffled by the wind, complete the rustic scenery." 50

At the same time, H. Stahl noted the "numerous abandoned and vacant plots, especially below the Cotroceni hills" ${ }^{51}$. Until the 1930s, Grozăvești remained one of the least densely populated neighbourhoods (48 inhabitants/hectare) ${ }^{52}$.

The suburb, synonym to the outskirts, is one element of the concentric areas metaphor that accompanied, since mid $19^{\text {th }}$ century, Bucharest's progress towards modernity. Ulysse de Marsillac, while looking at an old map, was fascinated by this space structure:

"In the centre stands the royal palace, a fortress rather than a usual residence. The houses of the nobility are grouped around it like satellites around the main star, and next there are the miserable wooden shacks, poorly placed, collapsed over one another in the mud and serving as shelter for workers destined to manual labour." $\$ 33$

A half a century later, to $F$. Damé Bucharest was also a sum of three concentric areas: the city center had an appearance similar to Western cities; "next to it, and beginning to be influenced by it" there was the "area occupied by the population of workmen and by the small industry", where buildings multiplied, streets were outlined and lighting was extending ${ }^{54}$. In the third area, the outskirts were

"composed of immense plots of land where poor neighbourhoods were formed here and there, of Romanians, sometimes of Gypsies, who practice their crafts, such as wheelmakers, carpenters, blacksmiths, bricklayers, day laborers or workmen at some factory nearby. Close to these suburbs there are several factories, and their number is increasing every year, and then there are

\footnotetext{
${ }^{50}$ Cioflec 1966, 64.

${ }^{51}$ Stahl 2002, 81; Pippidi 2002, 62.

52 Sfinţescu 2002b, 211 .

${ }^{53}$ Marsillac 1999, 84.

${ }^{54}$ Damé 2007, 344-345.
}

vineyards, orchards, vacant plots, sand quarries etc. ${ }^{\text {"55 }}$

The three concentric circles represent the metaphor of a landscape that texts described as structured somewhat naturally, organically, by the natural evolution of things ${ }^{56}$. By a decision of the 1847 city council $^{57}$ in order to prevent fires such as the one of that year, Bucharest was divided into three concentric circles, "three circles of three ranks" 58 , each with its own construction regulations. Only in the first circle all buildings had to be "built of masonry and covered with roof tiles or iron" and to have "solid chimneys". The transition from the medieval town's random development to the regulated urban construction took Bucharest into modemity, together with the legitimation of such division ${ }^{59}$. Until the communist period, constructive efforts, often associated with demolition ${ }^{60}$, were mainly oriented towards the city center, a monumental space ${ }^{61}$ of new ministry headquarters, palaces, boulevards, an area meant for display, "for parade" ${ }^{62}$, and prestige ${ }^{63}$, a symbol of modernization and of the affiliation of the political class to Western values: "Bucharest - a great Western capital at the gates of Orient" (advertising slogan from the interwar period $)^{64}$. At the same time, the outskirts continued to expand, with houses made of wood and adobe, covered with "cardboard, wooden planks, sometimes with reeds, straw, husks" ". "Anything that misery can imagine and anything that the poor can invent to combat misery takes shape in our suburbs" The materiality of the landscape tends to be structured by writing, by discourse, by

${ }^{55}$ Damé 2007, 344-345.

56 On the space dynamics of this model, see Mihăilescu 1925, 150; 152-163; Mihăilescu 2003, $11-15,84-85,113-123,125-135,153-155$.

${ }^{57}$ Lascu 1997, 65; Cinà 2010, 186.

${ }^{58}$ Georgescu 1969, 64-65.

${ }^{59}$ On the systematization plans of $1914,1916,1919-$ 1921, 1935, see Pănoiu 2011, 186-193, 202-215.

${ }^{60}$ lorga 1939, 310, 312; Derer 1995.

${ }^{61}$ Iorga 1939, 312, 320.

${ }^{62}$ Voronca 1972, 237.

${ }^{63}$ Pippidi 2002, 9-10.

${ }^{64}$ Pippidi 2002, 10.

${ }^{65}$ Vîttosu n.d., 41-42; Mușeţeanu 1935, 13.

${ }^{66}$ Vîrtosu n.d., 15. 
systematization and zoning plans as means of "city improvement",67. Modernity marked for Bucharest the transition at the discourse level from the functional space structure of a lifestyle characteristic to a social class to the "population polarization" 68 , where the aristocracy and the merchants' neighbourhoods were grouped in the centre ${ }^{69}$. Engineering ("in order to know what our capital can provide in the future, we must know it scientifically") ${ }^{70}$, discipline (for an "anarchic and rural population"; "the general social Orientalism generates social anarchy, general indiscipline, anarchy of values, lack of pride, political cowardice, the nostalgia of filth and the all-corrupting politicianism") ${ }^{71}$, classification and segregation ("class hatred stems precisely from close knowledge of the lifestyle of the rich classes, and if hatred is already there it intensifies even more") ${ }^{72}$ materialized in concentric circles - gradual transitions from the centre to the outskirts. Projects were aimed both at functional and social zoning: "the central district", the military area, cheap housing districts around the industrial districts ("The number of hands warrant the life of an industry, as much as the capital and the markets") ${ }^{73}$, residential neighbourhoods ("in the elevated parts of the city, the more picturesque and less densely built ones, with more parks, where there would be no industry and no unsanitary houses") ${ }^{74}$. Even the image of the future, the Bucharest utopia, is outlined in concentric circles: "the commercial and administrative centre, then the central residential area, the area of cheap houses and industrial districts etc." 75 .

The city and its circles continued to expand, partly for the reason that "the majority of the population lead and leads a very modest life" ${ }^{\prime 76}$, and few had the means to live in the centre; according to a law

\footnotetext{
${ }^{67}$ Sfinţescu $2002 b, 177$.

${ }^{68}$ Pănoiu 2011, 99.

${ }^{69}$ Iorga 1939, 286; Marsillac 1999, 125.

${ }^{70}$ Dobrescu 2002, 269.

${ }^{71}$ Dobrescu 2002, 274, 297.

${ }^{72}$ Sfinţescu 2002b, 252.

${ }^{73}$ Sfintescu 2002a, 123.

${ }^{74}$ Sfinţescu 2002b, 253; see also, Dobrescu 2002, 282.

${ }^{75}$ Iancu 1934, 14-15.

${ }^{76}$ Sfinţescu 2002a, 115
}

from 1894, the Western limits were marked by the Ghencea Cemetery, the Military Pyrotechnics, and Macedon's Mill (Ciurel) ${ }^{77}$. This marginal position of Grozăvești and Cotroceni encouraged various writers who were influenced by the city's capitalist changes to look back nostalgically at the times when the hills around Bucharest were covered in vineyards and orchards. In 1902, G.M. Ionescu was under the illusion that "after the completion of the Dâmboviţa channel between the Hydroelectric Plant and Ciurel - which is under intensive construction Cărămidarii de Sus will become, - once the now vacant plots are drained and planted an entertainment area like the ones that were once popular with the old and merry Bucharest townspeople."78

\section{THE GROZĂVEŞTI PARK: THE} "STRATIGRAPHY"

Each trench has its own "stratigraphy", a sequence of deposits of black, brown and grey soil. The construction materials found here did not belong to buildings or paths. They were not positioned in any order; sometimes they were next to each other, other times scattered or associated to other items or waste. The observed "layers" can only be interpreted as marks of consecutive depositions on the surface of the researched land. We were generally able to note that in the Eastern and Western sectors the filling consisted mainly of soil and building material debris, waste, and a few items. In the trenches of the central part of the investigated area there were thick deposits of massive concrete pieces as well as other building materials.

\section{GROZĂVEȘTI-COTROCENI-MILITARI: THE MONUMENTALIZATION OF THE OUTSKIRTS}

"Houses can no longer remain scattered disorderly on the edge of muddy lanes. Houses must be built solidly, in a constructivist manner, wholly marking the

\footnotetext{
${ }^{77}$ Georgescu et alii 1965, 362.

${ }^{78}$ Ionescu 1902, 547-548.
} 
harsh sensitivity of our time",79. During the interwar period, the avant-garde architect Marcel Iancu dreamt of a Bucharest with a centre of "tower residences where 60 stories would house almost 30,000 living souls" with a $400 \mathrm{~m}$ distance between them, amidst generous parks. Towards the outskirts there would be "cheap apartments in immense buildings measuring $400 \times 200$ $\mathrm{m}$, and housing 25,000 living souls each, also enclosing gardens with pergolas, areas meant for sports and for strolls, almost as big as our Cişmigiu Garden". "An iron will and an iron fist, such as Bucharest has known before, and the utopia will become reality" ${ }^{" 80}$. During the communist period, the outskirts were monumentalized, and transformed into the "New City" ${ }^{81}$. "Massive constructions are especially foreseen for the marginal city areas, which shall form well-aggregated self-contained units, ranked structurally". The housing districts accompanied the monuments of socialist industrialization ${ }^{82}$, and 32,600 apartments were built only between 1958$1961^{83}$. The decision of the November 1952 party assembly was to issue a Bucharest systematization and reconstruction plan that would ensure the "unitary and harmonious development, the good organization and allocation of land, and the end of the contrast between the centre and the outskirts",84.

A guide dating from the interwar period mentioned in the CotroceniGrozăveşti area the channelled Dâmboviţa river, the Cărămidarii de Sus church, the Botanical Garden, food markets on the Independentei Causeway and at the Grozăveşti Bridge, the Central Power Plant, Primary School No. 38, a Popular Athenaeum, the "Light of Grozăveşti" credit co-operative, some second-rate restaurants ("Marinescu N.", "Parcul Grozăveştilor", "Parcul Pascal", "Parcul

\footnotetext{
${ }^{79}$ Voronca 1972, 205.

${ }^{80}$ Iancu 1934, 15-16.

${ }^{81}$ Mihăilescu 2003, 165-166.

82 Boia 1968, 368; Lascu 1995, 173.

${ }^{83}$ Cebuc 1964, 116; for additional data, Zahariade $2011,44$.

84 Daiche 1965, 144; on the importance of this document, Zahariade 201 1, 25-33.
}

Mateescu"). On the plateau there were the various military headquarters, the Royal Palace and the Cotroceni train station nearby, and the "Leul"/"Lion" monument (dedicated to the fallen soldiers of the engineering battalion) ${ }^{85}$. Various city guides dating from the communist period restricted this list to the Culture House, Botanical Garden and former royal palace ${ }^{86}$, the "Military Engineers Monument" ("Leul") and the Grozăveşti power plant ${ }^{87}$. Initially, in this part of town the communist project continued, incorporated, manipulated and transformed the old significance of the liberal modernist project. The names of some streets were changed (for example the I.G. Duca Boulevard became the Armata Poporului/People's Army Boulevard). The Cotroceni palace functioned between 1949 and 1976 as the Pioneers' Palace ${ }^{88}$, "the place where our fatherland's future citizens grow up and are being educated", ${ }^{\prime \prime}$. After the 1977 earthquake, until 1988, the building was restored "in order to be used for high-level representation"90. In 1968 the church was transformed into a Museum of Old Religious $\mathrm{Art}^{91}$. Moreover, the church was omitted from a city guide issued in $1962^{92}$, and was later demolished in 1984. Texts published during the communist period celebrated the socialist industrialization ${ }^{93}$, the new apartment buildings on the Ammata Poporului Boulevard ${ }^{94}$ together with the mythical birth of the new era, "the anti-fascist uprising" 95 . The area acquired a mixed appearance, blending together the image of a district of apartment buildings (especially on the Armata Poporului Boulevard) ${ }^{96}$ and

\footnotetext{
${ }^{85}$ Ghid 1934, 25, 26, 70, 72, 77, 114-115, 120.

${ }^{86}$ Vintilă 1961; Ionescu, Kiriac 1982.

${ }^{87}$ Georgescu et alii 1970, 168-170.

${ }^{88}$ Giurescu 1966, 395, fig. 237; Opriș 1993.

${ }^{89}$ Stoicescu 1961, 50.

${ }^{90}$ Opriş 1993.

${ }^{91}$ Ciho et alii 1993, 174.

${ }^{92}$ Stoica et alii 1999, 114.

${ }^{93}$ Giurescu 1966, 218; Giurescu 1979, 188; Ionescu 1982.

94 Vasilescu 1967.

95 Vintilă 1961, 11

${ }^{96}$ Giurescu 1979, 319.
} 
the industrial and academic landscape ${ }^{97}$ : a clothing factory built in 1948 around a core consisting of military clothing workshops (APACA $^{98}$, the Electrical Machine Plant ${ }^{99}$, the Polytechnic Institute and the student dorms on the quay, which were erected in several stages starting from $1962^{100}$, and the Ştefan Gheorghiu Academy, built in $1975^{101}$. In the $1980 \mathrm{~s}$, the decision to transform the Cotroceni complex into the presidential residence led to the diversion of the tram routes on the Grozăvești Road towards the West, on Ho Chi Minh Road, which separates the area we investigated from the Polytechnic Institute. During the same period, Dâmboviţa was rearranged as a river flowing through a concrete channel. Simultaneously, the Bucharest metro construction works (begun in 1975) was conducted; various metro lines were inaugurated in several stages ${ }^{102}$.

Although official discourse assumes that texts reflect reality, in fact they rather reshape it. "The socialist city is the carrier and the propaganda agent of communist ideology" 103 . "The city development is organized by party and government decision, in functional directions that correspond to urban life: work, living, rest, education and recreation" 104. Neighbourhoods of apartment buildings divided by green areas and industrial platforms connected by public transport lines: the concentric circles metaphor was replaced by the transport network city. V.I. Lenin wrote in an article published in 1902 that the modern world was the theatre of confrontation of two ideologies: bourgeois and communist, and there was no place for a third ideology ${ }^{105}$. This confrontation also materialized in the change of the urban landscape. The functionalism that structures the city in practice was overcome by

\footnotetext{
${ }^{97}$ Mihăilescu 2003, 182-185.

${ }^{98}$ Giurescu 1966, 218; Giurescu 1979, 188; Ionescu 1982, 609-610; Chelcea 2008, 189-190.

${ }^{99}$ Giurescu 1966, 218; Chelcea 2008, 190.

${ }^{100}$ Daiche 1965, 156; Giurescu 1966, 255 fig. 174; Ionescu 1982, 630, fig. 448.

${ }^{101}$ Ionescu 1982, 631.

102 Olteneanu 2005; Cinà 2010, 238-239.

${ }^{103}$ Velescu 1995, 184.

${ }^{104}$ Stănescu 1972, 422.

${ }^{105}$ Lenin 1954, 165; see also Besançon 1977, 7-8.
}

discourse. To Lenin, industrialization was not a technical issue, but a materialization of social progress ${ }^{106}$. Apartment buildings are not just dwelling spaces, and factories are not just steel producing units. They are also monuments that create a specific space $^{107}$. Apartment buildings are symbols of faith in technology and in the progress brought about by industrialization, of the official preference for the nuclear family, of the ideology of social equality ${ }^{108}$. Industrial monuments mapped on economic maps in geographic atlases and textbooks define a harmonious space built by the party ${ }^{109}$.

THE GROZĂVEŞTI PARK: ARCHAEOLOGICAL EXCAVATIONS RESULTS

The Bucharest map made by the Military Geographic Institute between 1895-1899, as well as the one of $1914^{110}$, show the land currently occupied by the Grozăveşti Park in the river meadow area, occupied by gardens. According to a map from $1911^{111}$, the land was approximately $10 \mathrm{~m}$ lower than the prolongation of the hill on the route of the Grozăvești Road (PI. 2). It was a part of the meadow, a "pit" also shown by an updated map from 1965 (PI. 3 ). This was confirmed by archaeological excavations. The park was built on an artificial mound, a location covered with large quantities of landfill, pieces of concrete (Pl. 7/1) mixed with truck parts, wires, plastic and other kinds of waste. Geoelectric research (see Annex) indicated that the filling layer reaches a depth of $8 \mathrm{~m}$ (corresponding to the difference of level revealed by the above-mentioned maps; Pl. 3-4). Thus, an area of the Dâmboviţa river meadow, a "pit" was transformed into a hill, as the ground was elevated to the level of the hill prolongation descending from Cotroceni. An image of the "aesthetics" of such landfill can be given by the immense

\footnotetext{
${ }^{106}$ Hannemann 2004; Zahariade 2011, 35-36.

${ }^{107}$ On the monumentality of the communist space, see Mihali 2009, 271.

${ }^{108}$ Hannemann 2004.

${ }^{109}$ Daiche 1965; Boia 1968.

110 Sâmboteanu, Moldoveanu 1938; Sâmboteanu, Moldoveanu 1939; Stoica et alii 1999, 183.

${ }^{111}$ Chelcea 2008, 103 map no. 7.
} 
mound of soil and construction materials produced by the works on a building foundation next to the Ecology House, under construction at the time of our research in 2007 (PI. 7/2) or by the photographs of the debris of buildings that collapsed during the 1977 earthquake ${ }^{112}$. In short, our research was conducted in a waste dump covered in grass, paths and trees. The gathered information revealed that this radical change of the land was due to the works on the Bucharest metro, between 1977-1981/1983, when the Grozăveşti and Politehnica metro stations were built; the 1977 earthquake also occurred during the construction of the Politehnica metro station: many of the materials deposited in the "pit" might have originated from the buildings that were destroyed by the earthquake (information provided in 2005 by engineer Gheorghe Todoran of the metro company). Probably in 1989 (Pl. 6) trees were planted in a layer of the deposited filling and several concrete paths were cast, as well as a flowerbed. The vegetation, the planted trees, the concrete pavement paths, the now dilapidated flowerbeds concealed the industrial effort to modify the landscape. The park built on this waste dump gives "archaeological quality" to construction materials, pieces of concrete and bricks, annihilates their connection to the communism of the grey world of inhabited apartment buildings, of administrativeacademic buildings constructed during the same period, but still continuing to exist to this day. Reconfiguring materials into a waste dump hidden from view by a park confers the waste a communist aura. On the other hand, the academic buildings and the apartment buildings erected during the communist period, with bank offices established on their ground floors after 1989 , are integrated to a continuous present time, to an advertising billboard space. In the park, the archaeologist's eye opens when it comes across the materiality of ruin and of this present time.

\footnotetext{
112 Buhoiu 1977.
}

THE GROZĂVEŞTI PARK: MACHINERY AND BUILDING MATERIALS, OR ON THE BUCHAREST UTOPIA

In the excavated sections we found:

Steel wire, large pieces of concrete (including some with reinforcing bars), fragments of rail sleepers, pieces of cloth, marble tiles of the kind that can be found in metro stations, bricks, some of which were held together with mortar, pavement stones, pieces of pipes, pipes similar to those used for fountains, Terracotta oven tiles, a tube belonging to a well shaft, three truck tires, one cinder block, rubber fragments, plastics, three small infantry shovels, tractor parts, one engine oil filter produced by CARFIL-Braşov, one street elbow, cables from a fuse box, pieces of burned wood, an iron beam used for the metro constructions as support for slopes, the plastic cover of a fuse box, pitch used to insulate electric cables, aluminium cables, a piece of plywood, a cable and a rectangular section metal pipe, yellow and black plastic pipes, one lever, one line valve, copper transformer cables, a sidewalk block, an iron pipe and a clutch disk, tiles, stones, pieces of tin, a PVC conductor pipe, furnace chamotte.

The artificial mound of soil, pieces of concrete and cement, asphalt, discarded items rapidly became a "natural" form, eternal as the Earth itself. The park displays a solid foundation, a symbiosis of natural and artificial, as well as a materiality of the general mobilization of tools, machinery and materials. Drivers, workmen, soldiers. Production heroism is the defining feature of a socialist citizen, "the essential education factor" according to Nicolae Ceauşescu ${ }^{113}$. The presidential decree regarding the state of necessity after the 1977 earthquake mobilized party activists, army units and Interior Ministry units, patriotic guards, socialist production units, the whole able bodied population 114 . However, in the communist regime daily life, total mobilization for production was a common situation.

\footnotetext{
${ }^{113}$ Buhoiu 1977, 5.

114 Buhoiu 1977, 8-9.
} 
In the case of Bucharest, there was a perpetual state of emergency as regards rendering space representative. Since 18501860 (which marked, according to N. Iorga, the end of the old town $)^{115}$ all eyes were on the future and the past was left to only a few nostalgic voices. "Striving towards the utopia compels the city to permanently overcome itself and to permanent selfdestruction" "116 "The material available to the city planner is immense, the means are revolutionary and the plan must be utopic"117. "We find ourselves nowadays in a stage of complete recovery. The commercial centre grows vertically, the uncomfortable old houses make room for blockhouses in the centre, and the few yards and gardens are disappearing every moment"118. "[T]he ruthless demolition of the centre is necessary in order to allow for circulation speed and for free space for hygiene" "119. "Levelling. Cutting the MihaiVodă Hill in order to open a new boulevard" 120 . Projects that seemed forgotten were resumed unexpectedly. The Government Palace and the ministries that were to surround it were imagined by Ulysse de Marsillac in the $19^{\text {th }}$ century ${ }^{121}$. The idea to build a National Redemption Cathedral appeared in the interwar period; "the first attempt to dig a $60 \mathrm{~km}$ navigable channel supplied with water by a stream deviated from the Arges river in order to connect the Danube to Bucharest belonged to Charles II" ${ }^{122}$. C. Sfinţescu had previously envisioned a navigation channel on which barges would carry materials as far as the Grozăvești $\mathrm{dam}^{123}$. On the other hand, the former mayor Dem. I. Dobrescu pleaded for covering the Dâmboviţa river "in order to transform it into a channel" with "stations build underground"124.

\footnotetext{
115 Pippidi 2002, 42.

${ }^{116}$ Groys 2007, 71

${ }^{117}$ Iancu 1934, 7.

${ }^{118}$ Iancu 1934, 10.

119 Dobrescu 2002, 273; see also Iancu 1934, 17-20.

120 Stahl 2002, 131-135.

${ }^{121}$ Ionescu 1999, 20.

122 Caranfil et alii 1936, 12-15; Nemetescu 1943, 21-

28; Pippidi 2002, 10-11.

${ }^{123}$ Sfintescu 2002a, 143-149.

${ }^{124}$ Dobrescu 2002, 276, 284.
}

The urban space modernity discourse was oriented both towards a past that needed to be demolished or remodelled and especially towards the future. It celebrated its finished or imagined state, the visible features, the monumentalized landscape, the official cultural and political buildings, the residential districts, the factories. Models of factories or of apartment buildings neighbourhoods served not only for building project presentations (a stage prior to construction) but were also reproductions, miniature monuments that often became gifts for Ceauşescu. The archaeology of the contemporary past reveals the destruction process concealed by the discourse. It reveals the nude state of modernity, that of a perpetual unfinished project, subject to metamorphosis, the construction, destruction, and reconstruction, for which the world has become more ephemeral than a human being.

\section{THE GROZĀVEŞTI PARK: OBJECTS OR ON SOCIALIST HUMANISM}

In the landfill layers, together with building materials (Pl. 8): one yoghurt jar, two cans of fish in tomato sauce, canned in the USSR in 1982, a fragment of a green one liter bottle neck, fragments of porcelain dishes, the bottom of a clay pot (probably a flowerpot), the bottom of a clay bowl, a fragment of a glazed decorative plate, a plastic lid of a cup of "Făgăraş" cottage cheese and cream, an oyster shell, a fragment of a can labelled in Polish and Czech (with egg shells stuck to the lid), green glass sherds, the bottom of a porcelain mug, fragments of plastic sacks and bags, a mirror sherd.

During the first years of popular rule,
official discourse emphasized the struggle. Production heroes were celebrated in poems, became novel characters, were monumentalized by realist-socialist literary and artistic works. Official discourse celebrated construction sites, construction workers, masons. Paintings gave tribute to 
the Bucharest metro builders ${ }^{125}$. The Thesis of July 1971 (Ceauşescu's discourse on political-ideological activity) inaugurated a democratized image of proletarians, now transformed, beside the peasants and intellectuals, into working class members (oameni ai muncii). The class struggle was replaced by socialist, revolutionary humanism ${ }^{126}$. In 1973, the writer Alexandru Monciu-Sudinski provided a few characters (Caractere) ${ }^{127}$, working people whose biographies revolved around work and machines. A person's value was measured by his/her profession, job, skill, qualification, age. They went to night school and some still vaguely dreamt of college education. All those not doing physical work were considered intellectuals: phone operators, People's Council cashiers. An individual's development stages also revolved around work: (1) initiation, meaning "getting the hang" of a profession, (2) undergoing various stages of qualification, (3) teaching apprentices. Workmen appreciated landscapes to the extent to which they belonged to communist mythology: constructions, apartment buildings, new neighbourhoods. Attention, enthusiasm, intuition, consciousness, furnace, valve rocker, lathe, electrical oven, converter, Turbosol pump, meet the plan, confidence in the party. "We don't need embellishments. We need people, we need cast iron, we need truth". Monciu-Sudinski caricatured the ideal working man type that communism was trying to create ${ }^{128}$. The valve rocker reality from the point of view of Monciu-Sudinski's characters is closer to the music of the synchrophasotron and its "thirty-six thousand ton electromagnet", "the first cosmic organ" that sounded to Geo Bogza like Bach's and Beethoven's music ${ }^{129}$. Writers, historians, archaeologists, architects, philosophers, artists and filmmakers enrolled amongst the intellectuals that spread, popularized, aesthetized party

\footnotetext{
${ }^{125}$ Câmeci 2000, 133.

${ }^{126}$ Ceauşescu 1981.

${ }^{127}$ Monciu-Sudinski 1997.

128 On other interpretations of Caractere, see Manolescu 2005.

${ }^{129}$ Bogza 1959, 498-499.
}

politics - they belong to the world of Caractere. The working people who subscribed to the party's vision only existed in works which intellectuals attempted to make compelling enough to transform reality into the ideal world of official documents, filtered through artistic vibration and scientific accuracy. The works that mirrored the civic noninvolvement ethics, dwelling in the sphere of pure ideas, which some nowadays call resistance by culture, by mimicking and delivering the illusion of normality, all these also contributed not only to the legitimation but also to the reproduction of communism (the literary critic M. Niţescu asked intellectuals to participate in a "silent strike for a decade": "writers should either curse or be silent") ${ }^{130}$. After 1989, the dominant neoliberal discourse, which many intellectuals contributed to build, gradually turned against this class of working people, considered to have been mainly responsible for the perpetuation of communism, of obsolete mentality, dependent on the state and incapable to adapt to market economy. Its very identity was cancelled when socialist economy was destroyed. The term "worker" now refers to those working in factories, in the field, at the Post Office or for the secret services, including the former Securitate/Secret Police.

The archaeology of the communist past goes beyond such discourse and into the anonymity of daily life, of simple actions and rituals overlooked by words, to tell the story of eating canned fish on lunch breaks (moments of standardized industrial time), of discarding eggshells in an empty fish can, of mobilizing the military into the production field, of the yoghurt jar, of cottage cheese, glass containers, of souvenir sea shells, of the decorations and mirrors adorning private space. It reveals how these objects are incorporated in waste dumps, larger constellations that juxtapose cement and concrete (associated by official discourse to progress, industrialization, standardization, systematization) to bricks (elements of private space, of a backward

${ }^{130}$ Niţescu 1995, 378-379. 
nature, the materiality of ineffective manual labour) ${ }^{131}$.

"History is natural selection. Mutant versions of the past struggle for dominance; new species of fact arose, and old, saurian truths go to the wall, blindfolded and smoking last cigarettes. Only the mutations of the strong survive. The weak, the anonymous, the defeated leave few marks: field-patterns, axe-heads, folk-tales, broken pitchers, burial mounds, the fading memory of their youthful beauty."

Archaeology writes the story of those who never wore "the skin of a lion" (to paraphrase the title of Michael Ondaatje's novel), a faded rememoration of those who could not tell their own history.

\section{DEEP-SEA FAUNA AND THE SAILORS' SIREN}

\section{TATTOOS}

There is, as has been noted, a paradox of modernity: "having been founded on the myth of technology in itself, all the more durable as the critical spirit of modemity allowed itself to be enticed by it in the most irrational manner" ${ }^{133}$. "The mechanism of technology is only preoccupied with itself, with its own strictly technological issues. Any other human dimension is either swallowed and assimilated or rejected and destroyed ${ }^{\prime \prime 34}$. In this tautological universe, the archaeology discourse in Romania is narcissistically oriented towards celebrating its own "methods", lured by pluridisciplinarity running at idle, failing to explain phenomena by themselves - Paul Veyne's definition of functionalism ${ }^{135}$. The "framework" of an age can be reconstituted, according to avant-garde author Ilarie Voronca, from a single verse, as well as from a mere metal screw ${ }^{136}$. The dominant archaeological discourse in Romania has become trapped in the functional-

\footnotetext{
${ }^{131}$ Ioan 2000, 76-77; Hannemann 2004.

${ }^{132}$ Rushdie 1984, 124.

${ }^{133}$ Vais 2005, 77 (original emphasis).

${ }^{134}$ Hurduzeu 2005, 95 (original emphasis).

135 Veyne 1999, 347.

${ }^{136}$ Voronca 1972, 199, 249.
}

technological description of the metal screw and in the ecstatic contemplation of the act of finding a metal screw. Technology standardizes to the same extent the past, denying its alterity, and the writings about the past. By its propensity for tautological judgments ("a pit is a pit", "garbage is garbage"), in dialectical relation to "le refus de l'altérité, la négation du différent, le bonheur de l'identité et l'exaltation du semblable ${ }^{\text {"137 }}$, this effort could be included in what Roland Barthes called petitbourgeois mythology. Our excavation of a "filling" of the communist period revealed that, beyond its appearance, it is more than just a mere "filling". The pit turned into the hill on which the Grozăvești park was built is a fragment of the communist landscape, structured by a discourse that pointed both towards the past of the "bourgeoisie and landlords", striving to annihilate its remains, and the future, the time when communism would finally be built through heroic production. The pit was an illustration of the suburb concept, a metaphor of backwardness, a vestige of the old society. The socialist remodelling of the landscape needed to be vertical and uplifting, filling up the pits. The writer Ştefan Bănulescu, perched on the scaffolding of the $16^{\text {th }}$ floor of the future skyscraper at Sala Palatului, the tallest building in Bucharest at that time, saw the tops of socialist buildings, blocks of flats that he associated with light, air and colour, but his gaze also fell on the old "nonsystematized" neighbourhoods, with their humid and hazy atmosphere, with old houses with "wrecked and damp" foundations ${ }^{138}$. "In Soviet communism, any commodity became an ideologically relevant message, just as in capitalism any message became a commodity" ${ }^{139}$. The monumentality of the landscape built through discourse was a material proof of the construction of the new society, a wish to project it into eternity, cast in durable concrete. The city was "a long term investment, namely a vision of the future;

\footnotetext{
${ }^{137}$ Barthes 1957, 81

${ }^{138}$ Bănulescu 1960, 24-25.

${ }^{139}$ Groys 2009, 8.
} 
the synthesis of durability, a materialist ideology, the history of a country, the philosophy of existence" ${ }^{140}$. The steel whirlwinds of production transformed people together with the daily performance of urban landscape ${ }^{141}$. Ideology erected "monumental buildings, around which man himself becomes monumental" 142 . Words acquire a certain materiality, whereas the object becomes "narrative" taking the shape of message. A kind of object-words, wordobjects, cities with eyelashes, concentric circles, monuments that sometimes give life a meaning and more often than not crush people's destiny, shrill cries that stifle the utterance of people's own stories.

"Analysing history from the literary perspective is rather hazardous. It is like studying sailors' siren tattoos in order to learn about deep-sea fauna"143. However, archaeology is indeed a means of learning by the images of sailors' siren tattoos, by mirror reflections, by looking at the deepsea fauna through a glass, darkly. Seeking direct knowledge of the fauna by overlooking such interpretations that twine together the sea, the woman and the fish into one, namely the stories materialized into images which in their turn perpetuate the stories, is the surest way of transforming the past into an image of the present. This is exactly the difference between myth and science from Emst Jünger's perspective: "Here the world is interpreted, and there it is explained. If Palinurus fell asleep at the tiller, it was because a god touched his eyelids. A chemist would simplify this phenomenon down to the formation of lactic acid inside the tissue"144. Only such stories, narrations, myths, representations provide an image of the alterity of the past, the difference between various places and times which is, according to Philippe Ariès, similar to the "difference between two paintings or two

\footnotetext{
${ }^{140}$ Stănescu 1972, 421.

${ }^{141}$ O'Neill 2009, 93, 98-101.

142 Bogza 1959, 367; on the importance given by ideology to material culture as a transforming force that can shape the new man, Buchli 1997, 162; Buchli 2000; Tarlow 2002; Humphrey 2005.

${ }^{43}$ Sorescu 1985, 232.

144 Jünger 2004, 72.
}

symphonies". "La méconnaissance de la nature esthétique de l'Histoire a provoqué chez les historiens une décoloration complète des temps qu'ils se sont proposé d'évoquer et d'expliquer"145. The methods, the pluridisciplinary research, as well as the employed concepts and theoretical approaches, need to permeate archaeological writings durably but discreetly. They should no longer be their own purpose, but rather become what they are: instruments for learning about such stories. The literary space created by Melville for the white whale is closer to archaeology than a zoology study would be.

\section{ACKNOWLEDGEMENTS}

Preventive excavations conducted in 2005 and 2007 in the Grozăveşti Park in Bucharest were co-ordinated by Paul Damian, and I hereby thank him for the permission to publish the results. I am also grateful to my colleagues who helped me, both on site and with compiling the necessary documentation for drafting excavation reports: Valentin Bottez, Cristina Drăghici, Mihai Florea, Silviu Oța, Elvira Safta, Andra Samson. I wish to express thanks to engineer Gheorghe Todoran of Metroul S.A. for providing information on the context of the formation of the waste dump on which the Grozăvești Park was built; I also wish to thank Silviu and Emanoil Cristian Ene for the data on the communist past of the area. I am grateful to Viorel Petcu, who performed the test excavations in 2007, for the determination of the industrial items. Versions of this text have been read by Rodica Oanţă-Marghitu, Alexandru Dragoman, Tiberiu Vasilescu, Corina Borş, and I thank all of them for the corrections, notes and bibliography entries. Last but not least, I express my gratitude to Maria Krause for the English translation.

145 Ariès 1954, 285. 


\section{Ariès 1954}

Barthes 1957

Bănulescu 1960

Besançon 1977

Bilciurescu 2003

Bogza 1959

Boia 1968

Borş 1932

\section{Bourdieu 1977}

\section{Buchli 1997}

\section{Buchli 2000}

Buhoiu 1977

\section{Cantacuzino 1968}

Caranfil et alii 1936

\section{Cârneci 2000 \\ Ceauşescu 1981}

Cebuc 1964

Chelcea 2008

Ciho et alii 1993

Cinà 2010

Cioflec 1966

Cotroceni 1867

Daiche 1965

Damé 2007

Derer 1995

Dobrescu 2002

Duţu 1967

Filimon 2005

Florescu 1935

Georgescu 1969

\section{BIBLIOGRAPHY}

Ph. Ariès, Le temps de l'histoire, Monaco, 1954.

R. Barthes, Mythologies, Paris, 1957.

S. Bănulescu, Drum în câmpie, București, 1960.

A. Besançon, Les origines intellectuelles du léninisme, Paris, 1977.

V. Bilciurescu, Bucureşti şi bucureşteni de ieri şi de azi, Bucureşti, 2003.

G. Bogza, Scrieri în proză IV, București, 1959.

M. Boia, "Noi cartiere pe harta oraşului", Bucureşti, 6, 1968, 367-375.

L. Borş, “Azilul Elena Doamna”, Boabe de Grâu, Revistă de Cultură, educație a Poporului, Librăria de Stat, 3 (5), 1932, 147-165.

P. Bourdieu, "Une classe objet », Actes de la recherche en sciences sociales 17-18, 1977, 2-5.

V. Buchli, "Khrushchev, modemism, and the fight against petit-bourgeois consciousness in the Soviet home", Journal of Design History (Oxford), 10 (2), 1997, 161-176.

V. Buchli, An archaeology of socialism, Oxford, 2000.

A. Buhoiu (coord.), 4 martie 1977. Secunde tragice, zile eroice. Din cronica unui cutremur, Iaşi, 1977.

Gh.I. Cantacuzino, Mănăstirea Cotroceni, Bucureşti, 1968.

N.G. Caranfil, D. Pavel, D.R. Corbu, G. Vladimirescu, A.G. Vuzitas, Lucrările de asanare a lacurilor din Valea Colentinei, Bucureşti, 1936, extras din Buletinul Institutului Român de Energie 4 (4).

M. Câmeci, Artele plastice în România. 1945-1989, Bucureşti, 2000.

N. Ceauşescu, Omul şi afirmarea personalitătii sale în societatea socialistă, Bucureşti, 1981.

A. Cebuc, "Aspecte din viața unor mahalale bucureștene în perioada 19001944”, Materiale de Istorie și Muzeografie, 1, 1964, 101-117.

L. Chelcea, Bucureștiul postindustrial. Memorie, dezindustrializare şi regenerare urbană, Iaşi, 2008.

B. Ciho, M. Constantin, D. Folescu, G. Lupu, I. Opriș, A. M. Orăşanu, M. Pupeza, N.Vlădescu, Muzeul Nafional Cotroceni, București, 1993.

G. Cinà, Bucureşti, de la sat la metropolă. Identitate urbană şi noi tendinfe/Bucharest, from village to metropolis. Urban identity and new trends, Bucureşti, 2010.

V. Cioflec, "În Grozăveşti", in M. Mihalache (ed.), Mărturii despre Luchian, Bucureşti, 1966 [1907], 63-65.

Tabera Cotroceni din anulu 1863, București, 1867.

P. Daich, "Noi construcţii în capitala patriei", Materiale de Istorie şi Muzeografie, 2, 1965, 143-162.

F. Damé, Bucureştiul în 1906, Pitești, 2007 [1907].

P. Derer, "Istoria unei restructurări anunţate. 'Rădăcinile' restructurării zonei centrale din Bucureşti", Historia Urbana, 3 (1-2), 1995, 187-191.

D.I. Dobrescu, "Viitorul Bucureștilor", in A. Pippidi, Bucureşti. Istorie şi urbanism, București, 2002 [1934], 262-301.

A. Duţu, "Preocupări ale Consiliului Municipal din Bucureşti privind modernizarea industriei morăritului (1848-1900)", Bucureşti 5, 1967, 308317.

N. Filimon, "Grădinile din București. Buletinul orticol", in Nicolae Filimon, Opere, Bucureşti, 2005, 1054-1055.

G.D. Florescu, Din vechiul Bucureşti. Biserici, curţi boiereşti şi hanuri între 1790-1791 după două planuri inedite de la sfârşitul veacului al XVIII-lea, București, 1935.

F. Georgescu, „Focul cel mare' din martie 1847”, Bucureşti, 7, 1969, 55-66. 
Georgescu et alii 1965

Georgescu et alii 1970

Ghid 1934

Ghinea 1992

Giurescu 1966

Giurescu 1973

Giurescu 1979

Groys 2007

Groys 2009

Hanganu, Negru 2005

Hannemann 2004

\section{Harasim 1992}

Harasim 1993

Humphrey 2005

Hurduzeu 2005

Iancu 1934

Ioan 2000

Ionescu 1902

Ionescu 1969

Ionescu 1982

Ionescu 1999

Ionescu, Kiriac 1982

Ionnescu-Gion 1899

Iorga 1939

Istoria Cotrocenilor 2001

Jünger 2004

Lascu 1995

Lascu 1997

Lascu 2011

Leahu 2003

Lenin 1954
F. Georgescu, D. Berindei, A. Cebuc, P. Cemovodeanu, P. Daiche, S. Ionescu, P.I Panait, C. Şerban (ed.), Istoria oraşului București, I, București, Muzeul de Istorie a oraşului Bucureşti, 1965.

F. Georgescu, S. Ionescu, M. Cantili, Bucureşti oraşul nostru. Ghid, Bucureşti, Comitetul pentru Cultură şi Artă al Municipiului Bucureşti, 1970.

Bucureşti. Ghid oficial cu 20 hărti pentru orientare, București, Literatură și Artă "Regele Carol II", 1934.

N. Ghinea, "Sate din secolele XV-XIX pe teritoriul orașului București. Clanța, Cârstieneş̦ti, Herăstrău şi Băneasa", Bucureşti, 11, 1992, 78-92.

C.C Giurescu, Istoria Bucureştilor din cele mai vechi timpuri până în zilele noastre, București, 1966.

C. C. Giurescu, Contribuţii la istoria științei și tehnicii româneşti în secolele XV-inceputul secolului XIX, București, 1973.

C. C. Giurescu, Istoria Bucureştilor, București, 1979 (Second edition).

B. Groys, Topologia aurei şi alte eseuri, Cluj, 2007.

B. Groys, Post-scriptumul comunist, Cluj, 2009.

N. Hanganu, M. Negru, "Monede din secolele XVIII-XX descoperite în săpături arheologice pe teritoriul oraşului București", $C A B, 6,2005,369-376$.

C. Hannemann, Architecture as ideology: industrialization of housing in GDR, Berlin, 1995 (http://www.sowi.hu-berlin.de/lehrbereiche/stadtsoz' mitarbeiterinnen/a-z/hannemann/dateien/slab_of_gdr_eng.pdf; accessed: 2.10.2011).

A. Harasim. "Dealul Cotroceni-Azilul Elena Doamna", Bucureşti, 11, 1992, $165-178$.

A. Harasim, "Din istoria administrării Mănăstirii Cotroceni", in Colocviul româno-american , Cotrocenii în istorie. 15-18 iulie 1992", 1993, 21-29.

C. Humphrey, "Ideology as infrastructure: architecture and Soviet imagination", Journal of Royal Anthropological Institut N.S., 11, 2005, 39-58.

O. Hurduzeu, Sclavii fericiti. Lumea văzutã din Silicon Valley, Iaşi, 2005.

M. Iancu, "Utopia Bucureștilor", in M. Iancu, H. Creangă, O. Doicescu. Către o arhitectură a Bucureştilor, București, 1934, 7-20.

A. Ioan, Bizant după Bizant după Bizant. Teme ale arhitecturii în secolul XX. Cazul românesc, Constanţa, 2000.

G. M. Ionescu, Istoria Cotrocenilor, Lupescilor (Sf. Elefterie) şi Grozăvescilor, București, 1902.

S. Ionescu, "Dezvoltarea edilitar-urbanistică a oraşului Bucureşti la sfầrşitul sec. al XIX-lea", Bucureşti, 7, 1969, 81-97.

G. Ionescu, Arhitectura pe teritoriul României de-a lungul timpurilor, București, 1982.

A.-S. Ionescu, "Prefatăă", in Ulysse de Marsillac, Bucureştiul în veacul al XIX-lea, București, 1999, 5-21.

A. Ionescu, C. Kiriac, Bucureşti. Ghidul străzilor, Bucureşti, 1982.

G.I. Ionnescu-Gion Istoria Bucurescilor, București, 1899.

N. Iorga, Istoria Bucureştilor, Bucureşti, 1939.

Carmen Păsculescu-Florian, Marian Constantin (coord.), Istoria Cotrocenilor in docun rente (secolele XVII-XX), București, 2001.

E. Jünger, Pagini din Kirchhorst. Coliba din vie. Ani de ocupafie, Iaşi, 2004.

N. Lascu, "Modernizare şi distrugeri în istoria postbelică a orașelor româneşti", Historia Urbana, 3 (1-2), 1995, 171-177.

N. Lascu, "Bucarest au XIXe siècle et l'urbanisme moderne", Bucureşti, 12, 1997, 62-73.

N. Lascu, Bulevardele bucureștene până la primul război mondial, Bucureşti, 2011.

V. Leahu, Cultura Tei. Grupul cultural Fundenii Doamnei. Probleme ale epocii bronzului in Muntenia, Institutul Român de Tracologie, Bibliotheca Thracologica, 38, Bucureşti, 2003.

V.I. Lenin, "Ce-i de făcut? Probleme acute ale mişcării noastre", in V.I. Lenin, Opere alese în două volume I, București, 1954, 137-279. 


\section{Licherdopol 1889 \\ Macovei, Varga 1993 \\ Manolescu 2005}

\section{Marsillac 1999}

Mihali 2009

Mihăilescu 1925

Mihăilescu 2003

Monciu-Sudinski 1997

Muşeţeanu 1935

Nemetescu 1943

Nitescu 1995

Olivier 2008

Olteneanu 2005

\section{O’Neill 2009}

Opriş 1993

\section{Panait 1967}

Panait 1969

Panait 1978

Panait 1992a

Panait 1992b

Panait 2005

Panait, Ştefănescu 1981

Pănoiu 2011

Pippidi 2002

Popescu-Lumină 2007

Poll, Mănucu-

Adameșteanu 1997

\section{Rosetti 1929}

Rushdie 1984

Sâmboteanu,

Moldoveanu 1938

Sâmboteanu, Moldoveanu 1939
I.P. Licherdopol, Bucureştii, Bucureşti, 1889 (Tipografia Carol Göbl).

C. Macovei, L. Varga (ed.), Cotrocenii. Stampe de epocă, Bucureşti, 1993.

I. Manolescu, "Pe urmele lui Monciu-Sudinski", in P. Cernat, I. Manolescu, A. Mitchievici, I. Stanomir, Explorări în comunismul românesc II, Iași, 2005, 453-490.

U. Marsillac, Bucureştiul în veacul al XLX-lea, Bucureşti, 1999 [1869] [1877].

C. Mihali, "Oraşul precar. Consideraţii asupra condiţiei distopice a spaţiilor urbane postcomuniste", in Adrian T. Sârbu and Alexandru Polgár (coord.), Genealogii ale postcomunismului, Cluj, 2009.

V. Mihăilescu, Vlăsia şi Mostiştea (evolutia geografică a două regiuni din Câmpia Română), București, 1925, Buletinul Societătii Regale de Geografie XLIII.

V. Mihăilescu, Evolufia geografică a unui oraş - Bucureşti, Bucureşti, 2003.

A. Monciu-Sudinski, Caractere, Bucureşti, 1997.

I. Mușețeanu, Monografía Bisericii Cărămidarii de Sus (Grozăvești), Bucureşti, 1935.

G. Nemetescu, Bucureştii port la Dunăre. $C u$ o prealabilă descriere a originei şi istoricului acestui oraş, de la 1200 până azi, Bucureşti, 1943.

M. Niţescu, Sub zodia proletcultismului. Dialectica puterii, București, 1995.

L. Olivier, Le sombre abîme du temps. Mémoire et archéologie, Paris, 2008.

M. Olteneanu, "Metroul bucureștean", Univers ingineresc 18, 2005, 1-8 (http://www.agir.ro/univers-ingineresc/metroul_bucurestean_1165.html; accessed: 26.08.2011).

B. O'Neill, "The political agency of cityscapes. Spatializing govemance in Ceaussescu's Bucharest", Journal of Social Archaeology, 9 (1), 2009, 92-109.

I. Opriş, "Muzeul Naţional Cotroceni-expresia unei necesităţi publice", in B. Ciho, M. Constantin, D. Folescu, G. Lupu, I. Opriş, A. M. Orăşanu, M. Pupeza, N. Vlădescu, Muzeul Naţional Cotroceni, București, 1993, 5-10.

P.I. Panait, "Începuturile oraşului București în lumina cercetărilor arheologice", Bucureşti, 5, 1967, 7-24.

P.I. Panait, "Însemnări arheologice pe șantierele de construcţii din București (II)", Bucureşti, 7, 1969, 29-39.

P.I. Panait," "Consideraţii privind demografia teritoriului ilfovean în sec. XV-XVI", Ilfov. File de istorie, București, 1978, 169-172.

P.I. Panait, "Oraşul Bucureşti în timpul domniei lui Constantin Vodã Brâncoveanu", Bucureşti, 11, 1992, 46-67.

P.I. Panait, "Vattra satelor din jurul Bucureștilor în lumina cercetărilor arheologice (sec. XIV-XVI)", CAB, 4, 1992, 75-87.

P.I. Panait, "Arheologia Cotrocenilor", $C A B, 6,2005,247-268$.

P.I. Panait, A. Ștefănescu "Relaţiile oraşului București cu satele învecinate în secolele XIV-XVI", $C A B, 3,1981,107-129$.

A. Pănoiu, Evolufia orașului București, Bucureşti, 2011.

A. Pippidi, Bucureşti. Istorie şi urbanism, Bucureşti, 2002.

Colonel Popescu-Lumină, Bucureştii din trecut şi de astăzi, in V.Gh. Speteanu (ed.), Primii istoriografi ai Bucureştilor, Bucureşti, 2007 [1935].

I. Poll, Gh. Mănucu-Adameșteanu, "Brăţări de sticlă descoperite pe raza orașului București", București, 12, 1997, 23-30.

D.V. Rosetti, Din preistoria Bucureştilor, Bucureşti, Cronica Numismatică şi Arheologică, 1929, 89-94.

S. Rushdie Shame, London, 1984.

U. Sâmboteanu, M.D. Moldoveanu, Noul plan al municipiului Bucureşti cu indicatorul alfabetic al străzilor, Bucureşti, 1938.

U. Sâmboteanu, M.D. Moldoveanu, Noul plan al municipiului Bucureşti cu indicatorul alfabetic al străzilor, București, 1939. 
Schuster 1997

Sfințescu 2002a

Sfinţescu 2002b

Silvestru 1997

Slavici 1884

Sorescu 1985

Stahl 2002

Stănescu 1972

Stoica et alii 1999

Stoicescu 1961

Şerban 1978

Ştefãnescu 1981

Ştefănescu, Lazăr 2004

Tarlow 2002

Târnă 1997

Toma 2001

Vais 2005

Vasilescu 1967

Velescu 1995

Velescu 2007

Veyne 1999

Vintilă 1961

Vîrtosu (n.d.)

Voronca 1972

Voronca 1973

Zahariade 2011
C. Schuster, Perioada timpurie a epocii bronzului în bazinele Argeșului şi Ialomitei superioare, Institutul Român de Tracologie, Bibliotheca Thracologica 20, București, 1997.

C.I. Sfintescu "Studiu asupra planului general de sistematizare al capitalei", in A. Pippidi, București. Istorie şi urbanism, București, Dominor, 2002, [1919?], 102-146.

C.I. Sfinţescu "Zonificarea urbanistică a municipiului Bucureşti (zone de construcţii şi zone de verdeaţă)", in A. Pippidi, Bucureşti. Istorie şi urbanism, Bucureşti, Dominor, 2002 [1931], 176-261.

O. Silvestru, "Începuturile tramvaiului electric în București", Bucureşti, 12, 1997, 144-155.

I. Slavici, Asilul "Elena Doamna", Sibiu, 1884.

M. Sorescu, Uşor cu pianul pe scări, București, 1985.

H. Stahl, Bucureștii ce se duc, București, 2002 [1910].

T. Stănescu, "Dezvoltarea oraşului București în anii socialismului", București, 9, 1972, 421-429.

L. Stoica, N. Ionescu-Ghinea, D. Ionescu, C. Luminea, P. Iliescu, M. Georgescu, Atlas-ghid. Istoria şi arhitectura lăcaşurilor de cult din Bucureşti, I, Bucureşti, 1999.

N. Stoicescu, Repertoriul bibliografic al monumentelor feudale din Bucureşti, București, 1961.

C. Şerban, "O descriere puţin cunoscută a judeţului Ilfov din ajunul revoluţiei din 1821", Ilfov. File de istorie, București, 1978, 241-246.

A. Ştefănescu, "Consemnări arheologice pe şantiere de construcţii", $C A B, 3$, 1981, 265-278.

A. Ștefãnescu, M. Lazăr Mănăstirea Cotroceni - un monument istoric dispărut, Bucureşti, 2004.

S. Tarlow. "Excavating Utopia: why archaeologists should study 'ideal' communities of the nineteenth century", International Journal of Historical Archaeology, 6 (4), 2002, 299-323.

M. Târnă, "Alimentarea cu apă potabilă şi amenajarea sistemului de canalizare în Bucureşti (1870-1900)", Bucureşti, 12, 1997, 112-122.

D. Toma, Despre grădini şi modurile lor de folosire, Iaşi, 2001.

D. Vais, "Tehnologia ca ficţiune arhitecturală”, in C. Mihali (ed.), Artă, tehnologie și spafiu public, Bucureşti, 2005, 65-86.

Gh. Vasilescu, „Dezvoltarea cartierului Giuleşti după 1944”, București, 5, 1967, 341-351.

O. Velescu, „Ideologia <restructurării urbane>”, Historia Urbana, 3 (1-2), 1995, 179-186.

O. Velescu, "Cotrocenii în secolul al XVII-lea", București, 21, 2007, 179i 92 .

P. Veyne, Cum se scrie istoria, Bucureşti, 1999.

P. Vintilă. Bucureşti. Mic indreptar, București, 1961.

Gh. Vîrtosu, Locuinte pentru populatia nevoiaşă şi problema comasărilor, Bucureşti, Biblioteca Urbanistică 49-50.

I. Voronca Act de prezență, Cluj, 1972.

I. Voronca, Mic manual de fericire perfectă, București, 1973.

A.M. Zahariade Arhitectura in proiectul comunist. România 19441989/Architecture in the communist project. Romania 1944-1989, Bucureşti, 2011. 
LIST OF PLATES

Pl. 1 - Bucharest - Grozăveşti Park. Plan of the excavated areas

Pl. 2 - The field on which Grozăveşti Park was made. Plan from 1911

Pl. 3 - The field on which Grozăveşti Park was made. Plan from 1965 which was updated during the construction of the subway line

Pl. 4 - The field on which Grozăvești Park was made. Plan from 1987

PI. 5 - Bucharest - Grozăveşti Park. 1. View from the OMV gas-station and 2. from Vasile Milea Boulevard

Pl. 6 - Bucharest - Grozăveşti Park. Images from 2005

PI. 7 - Bucharest - Grozăvești Park. 1. „Filling” of S04/2007 sounding. 2. Configuration of a dump resulted from the works around the Ecology House (2007)

PI. 8 - Bucharest - Grozãvești Park. Objects discovered in different soundings (2005, 2007)

\section{LISTA ILUSTRATIEI}

Pl. 1 - Bucureşti - Parcul Grozăveşti. Planul general al săpăturii

Pl. 2 - Terenul pe care a fost amenajat Parcul Grozăvești. Plan din 1911

PI. 3 - Terenul pe care a fost amenajat Parcul Grozăvești. Plan din 1965 actualizat în perioada construirii metroului

Pl. 4 - Terenul pe care a fost amenajat Parcul Grozăveşti. Plan din 1987

Pl. 5 - Bucureşti - Parcul Grozăveşti. 1. Vedere dinspre benzinăria OMV şi 2. dinspre Bulevardul Vasile Milea

Pl. 6 - București - Parcul Grozăveşti. Imagini din 2005

PI. 7 - 1. București - Parcul Grozăveşti. „Umplutura” sondajului S04/2007. 2. Aspectul unei halde rezultată în urma lucrărilor din zona Casei Ecologiei (2007)

PI. 8 - Bucureşti - Parcul Grozăveşti. Obiecte descoperite în diferite sondaje $(2005,2007)$

\section{Sorin OANȚĂ-MARGHITU}

Muzeul Naţional de Istorie a României

Secția Arheologie

Calea Victoriei 12, 030026, Bucureşti.

sorinoanta@yahoo.com 

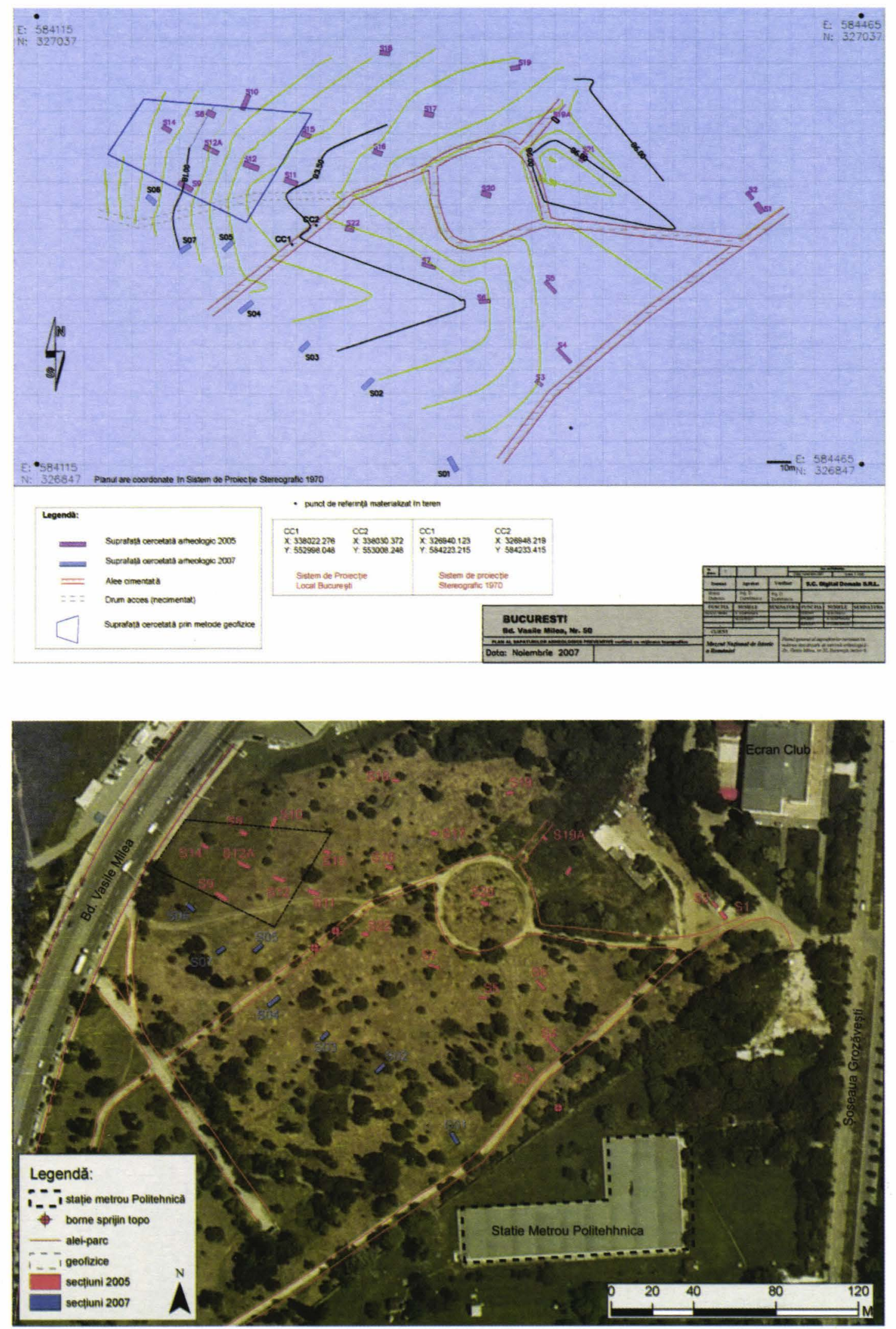

Pl. 1 - Bucharest - Grozăvești Park. Plan of the excavated areas. 


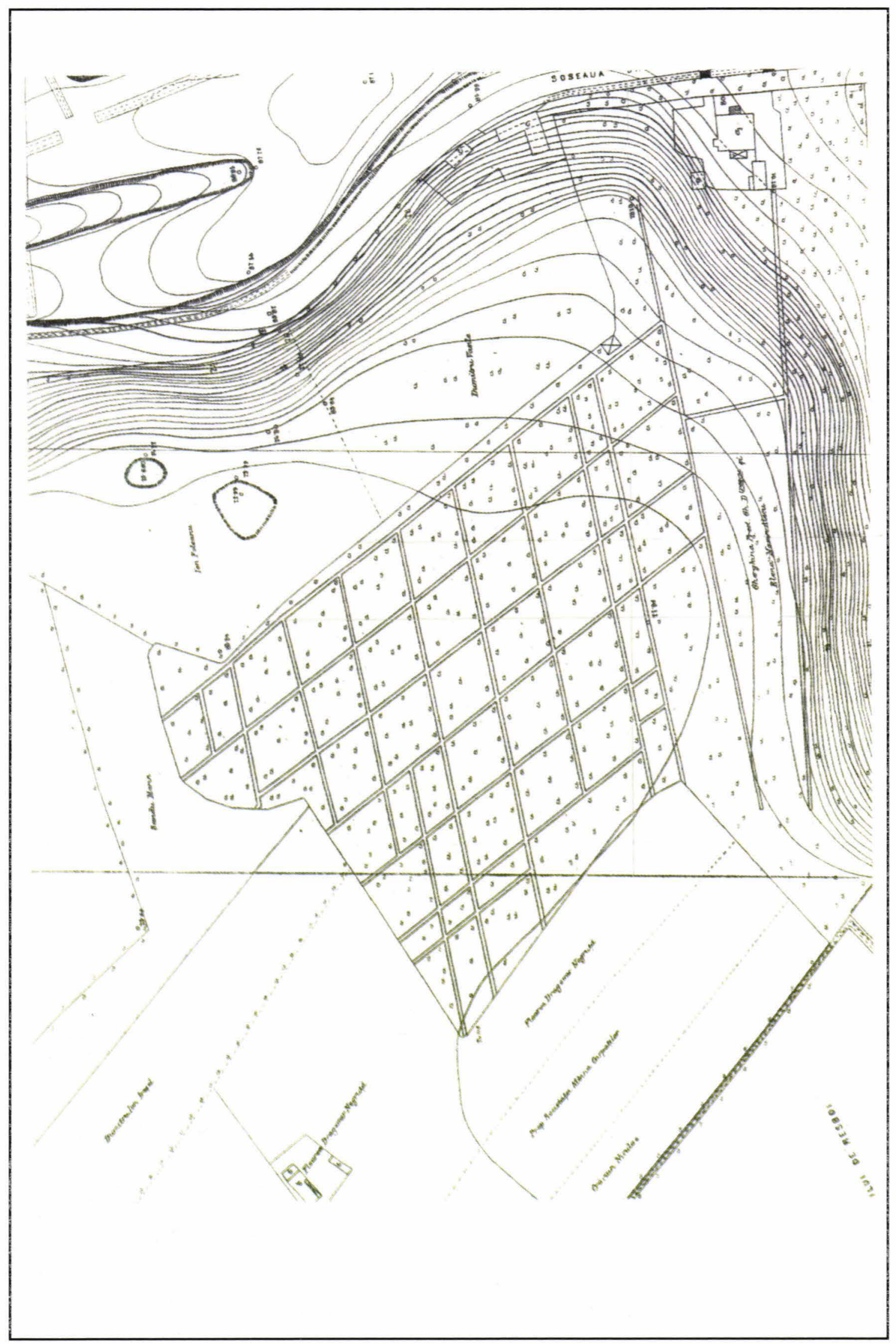

PI. 2 - The field on which Grozăvești Park was made. Plan from 1911. 


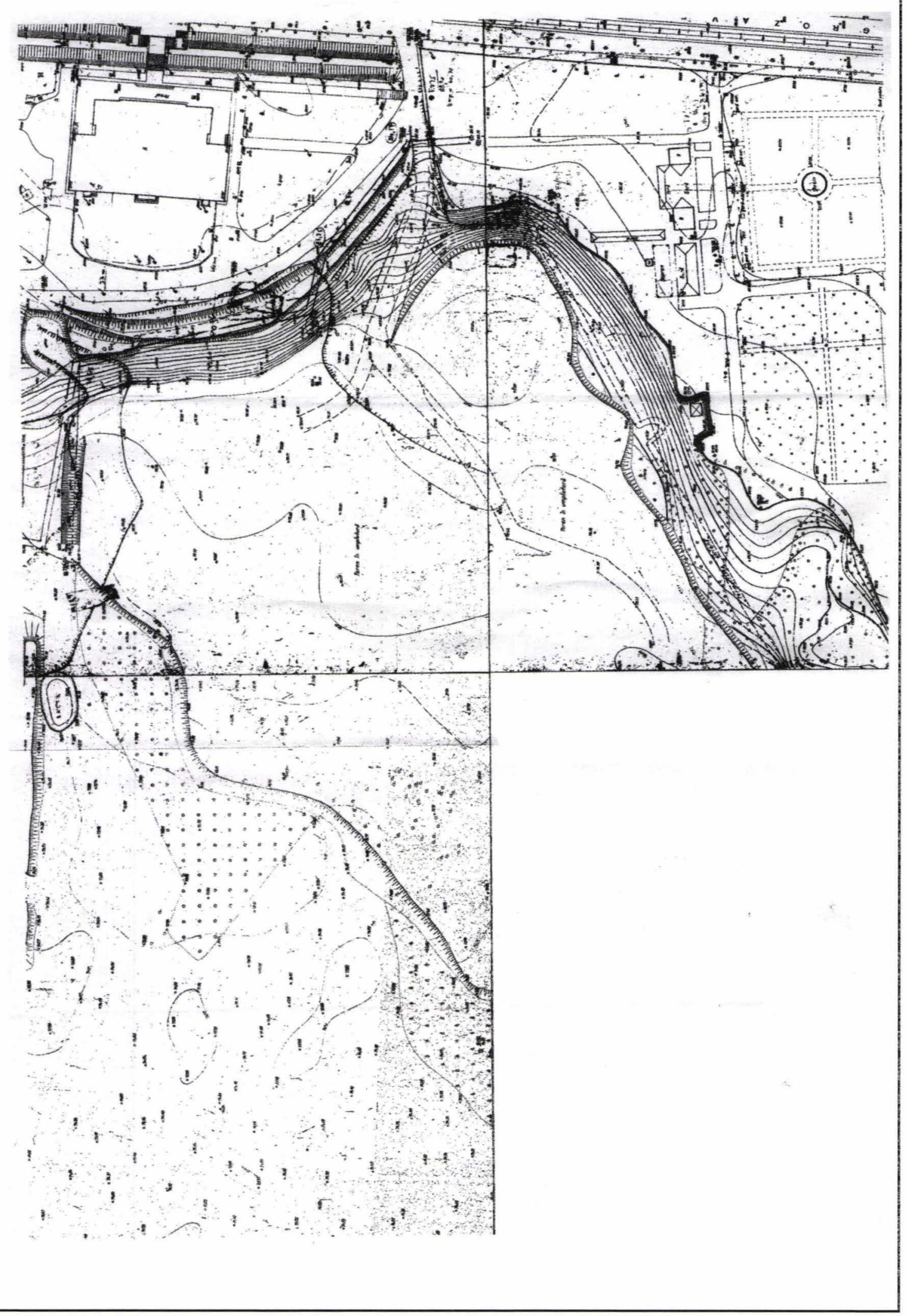

Pl. 3 - The field on which Grozăveşti Park was made. Plan from 1965 which was updated during the construction of the subway line. 


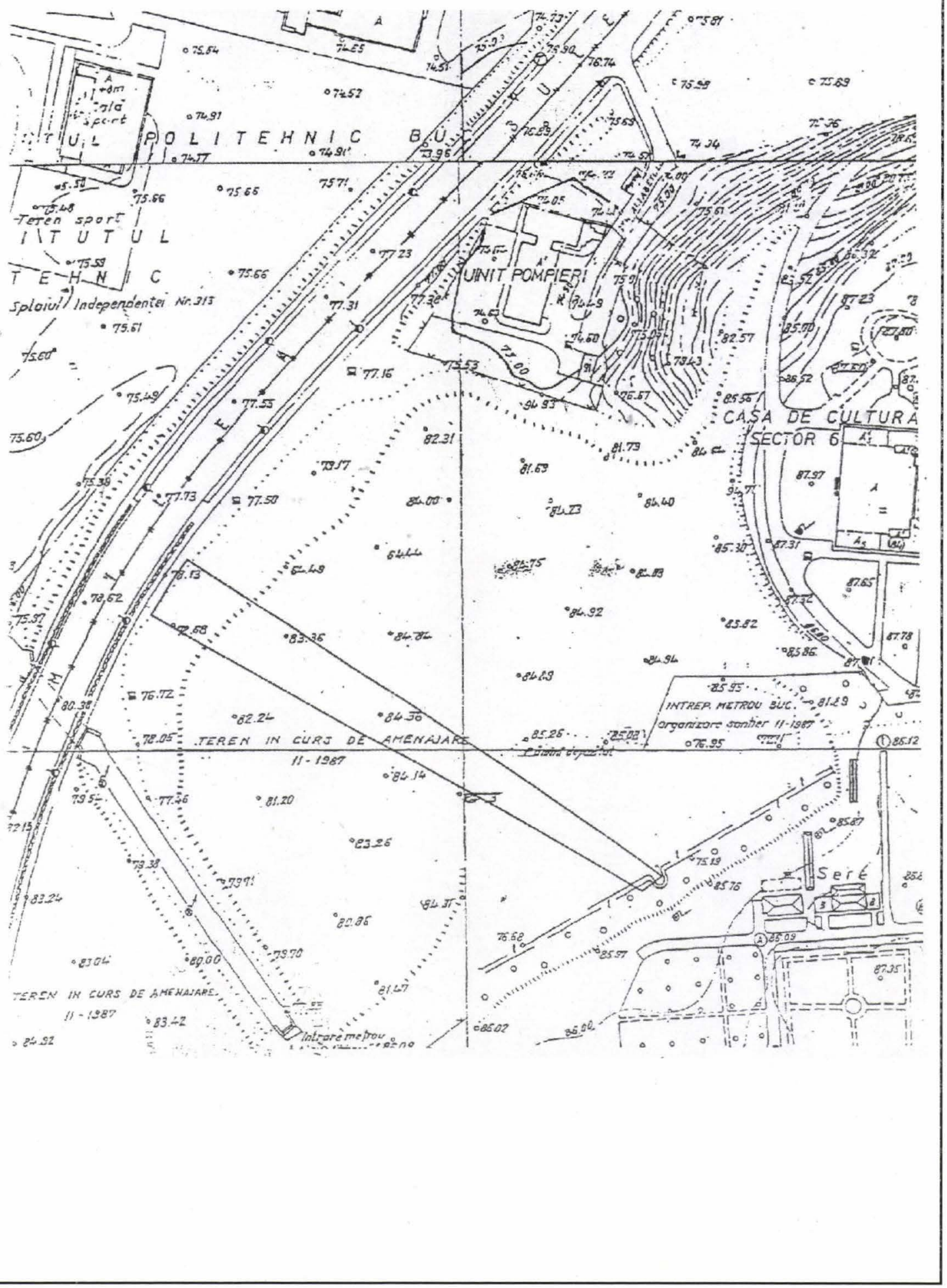

Pl. 4 - The field on which Grozăvești Park was made. Plan from 1987. 


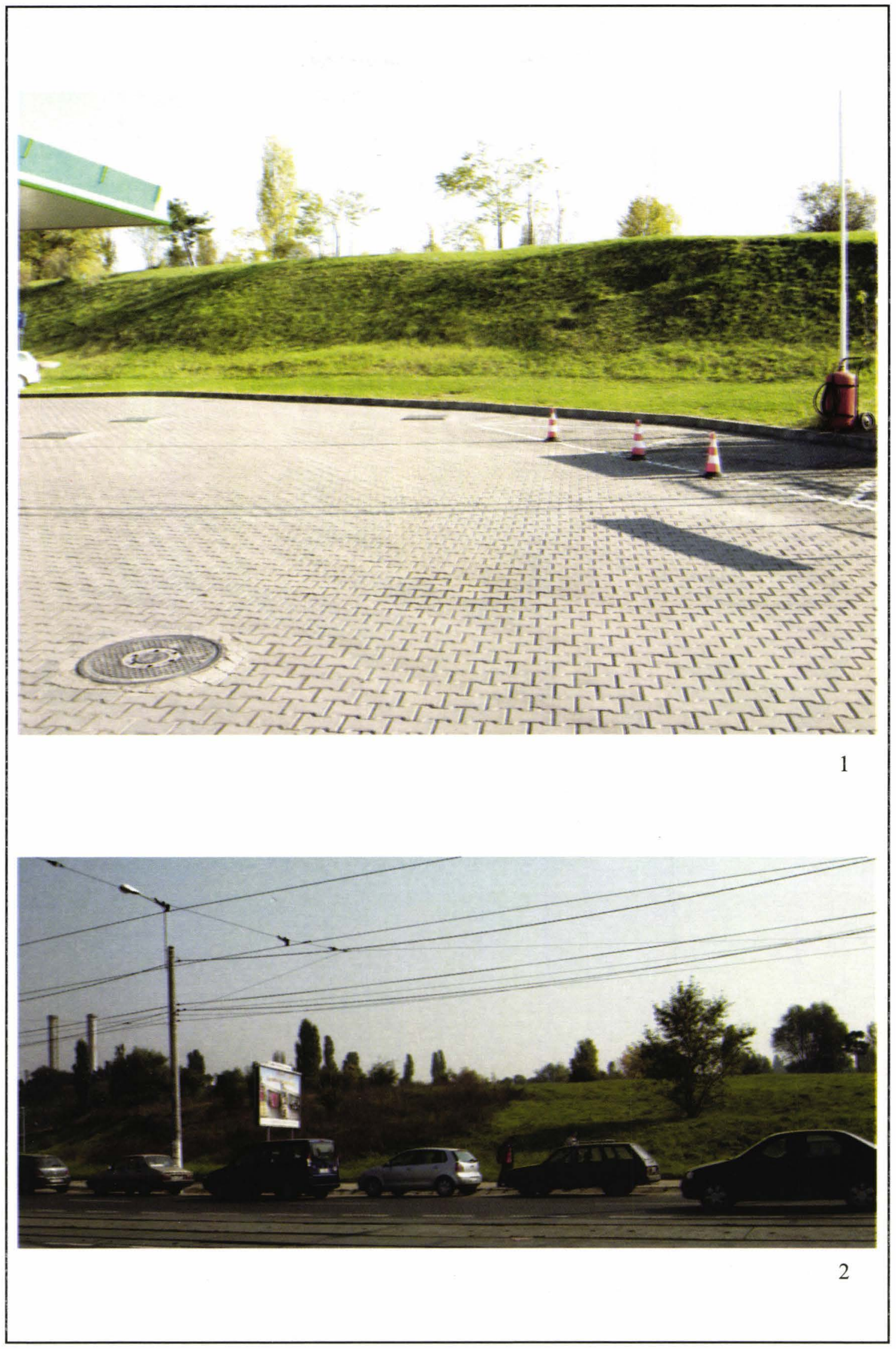

Pl. 5 - Bucharest - Grozăveşti Park. 1. View from the OMV gas-station and. 2. from Vasile Milea Boulevard. 

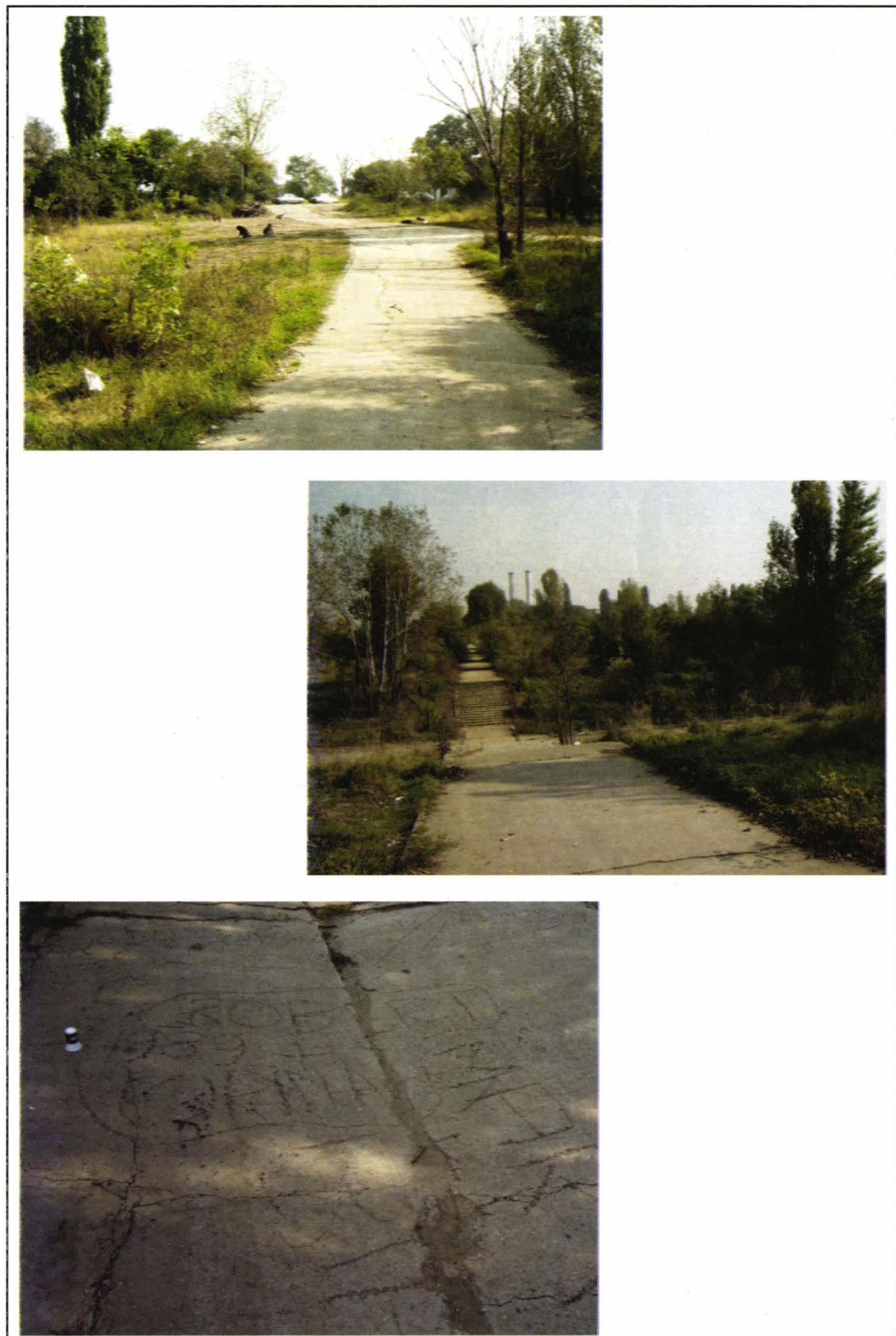

PI. 6 - Bucharest - Grozăvești Park. Images from 2005. 


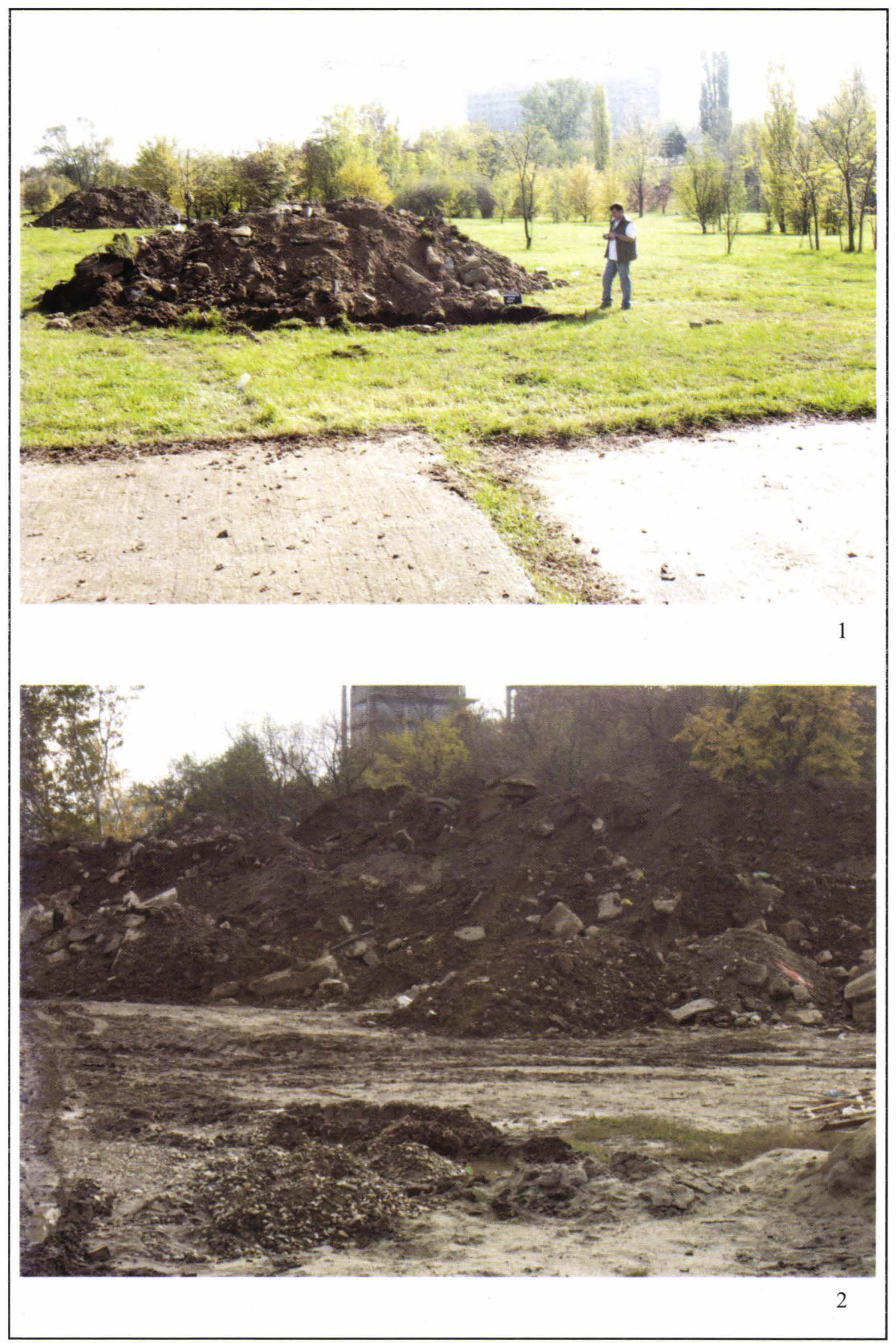

Pl. 7 - Bucharest - Grozăveşti Park. 1. „Filling” of S04/2007 sounding. 2. Configuration of a dump resulted from the works around the Ecology House (2007). 

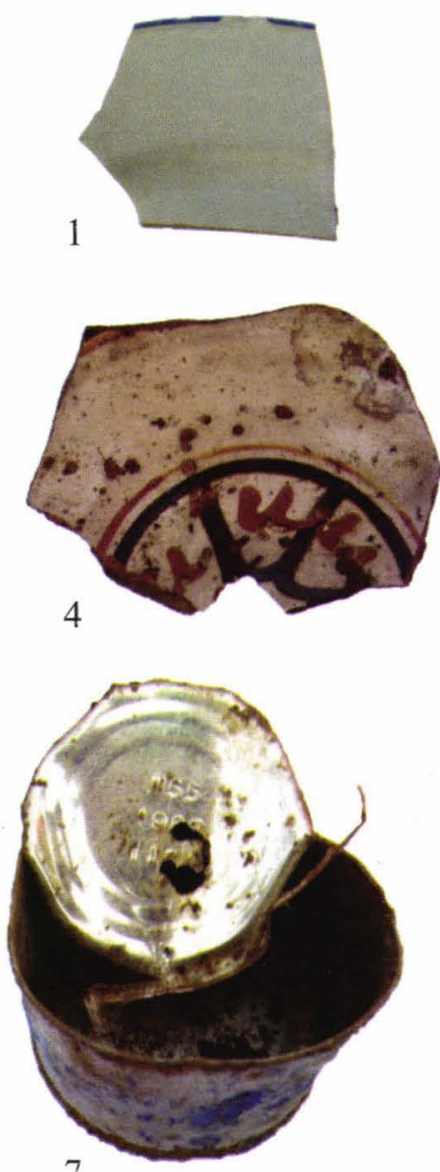

7

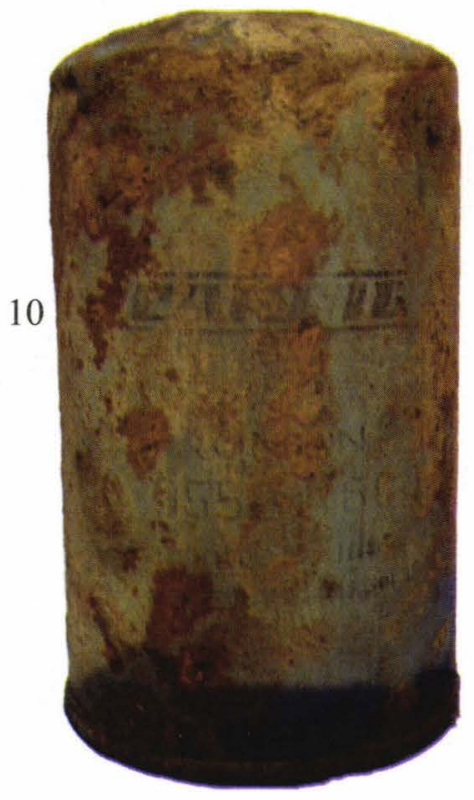

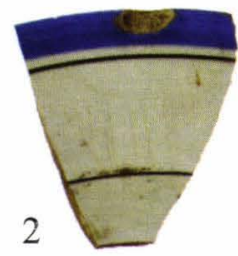
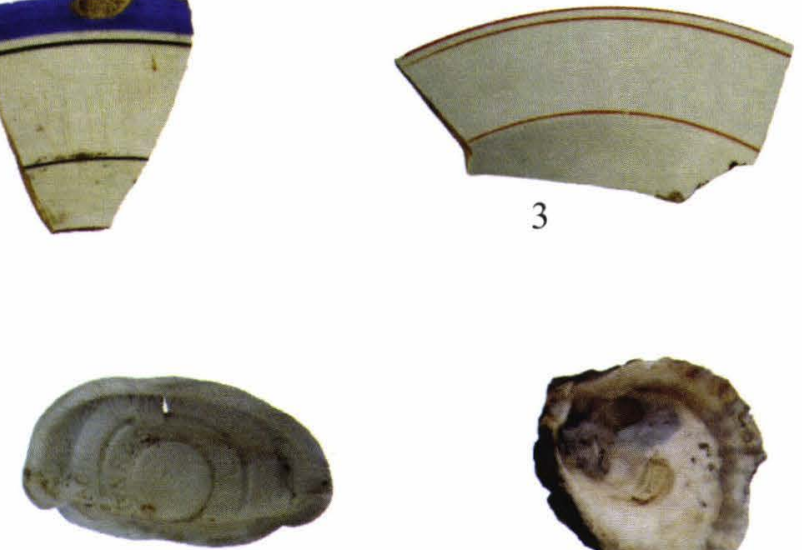

5
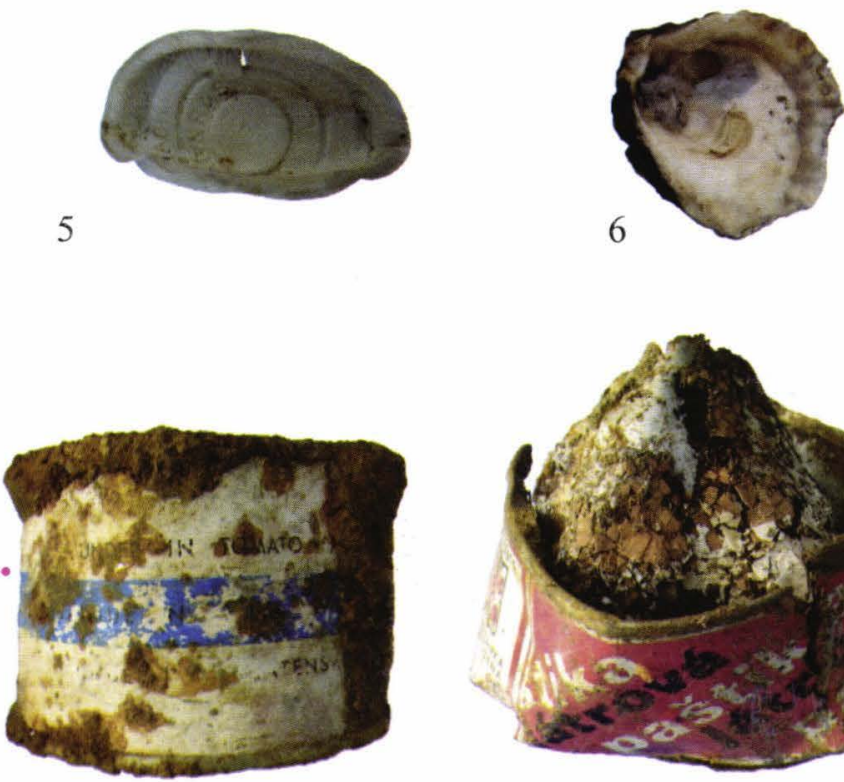

8

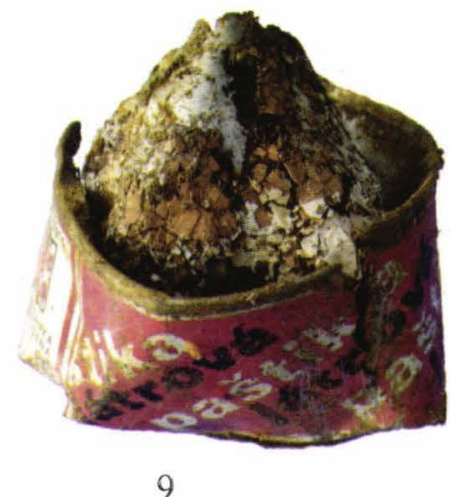

9

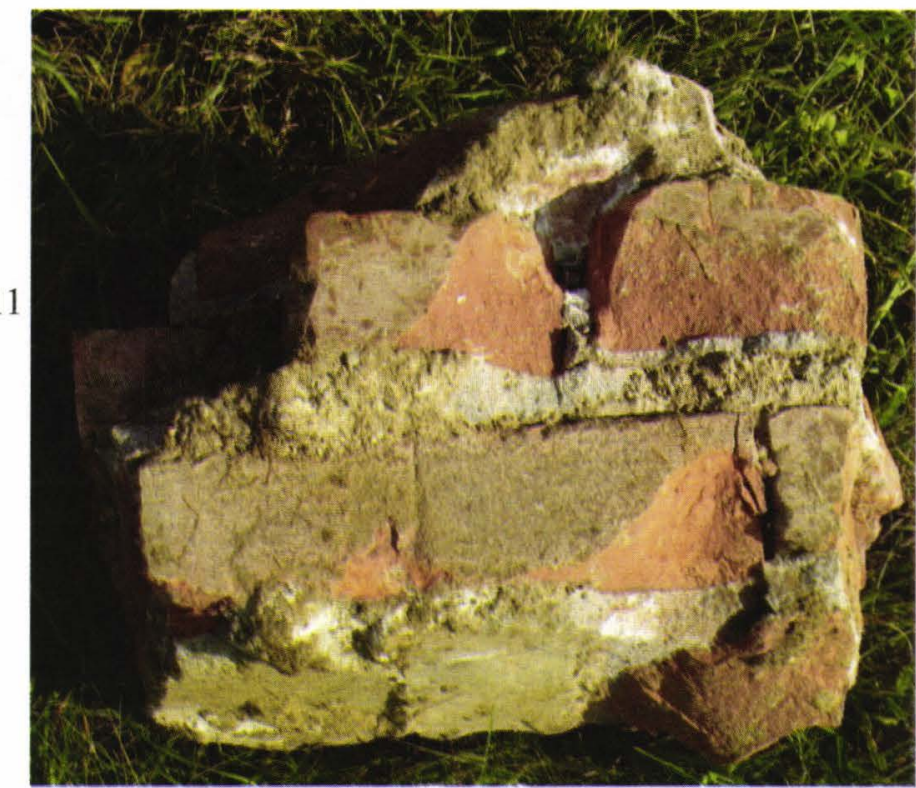

PI. 8 - Bucharest - Grozăvești Park. Objects discovered in different soundings $(2005,2007)$. 


\section{ANNEX \\ GEOELECTRIC RESEARCH IN THE VASILE MILEA BOULEVARD AREA}

Geoelectric measurements were conducted between 19.10.2005-22.10.2005 in the Vasile Milea Boulevard area (PI. 1) covering $7500 \mathrm{~m}^{2}$. The information obtained by prospecting covered a depth interval of 0 $3 \mathrm{~m}$. The distribution of apparent resistivity in the $0-3 \mathrm{~m}$ interval is illustrated in Pl. $\mathbf{2} / \mathbf{1}$. Recorded resistivity ranged between 10 and 35 ohmm, and the anomaly areas were situated at an interval of $25-35 \mathrm{ohmm}$. The maximum values areas represented inhomogeneity within the above-mentioned interval. A minimum value area was recorded on the E-W axis; this was due to high soil humidity, and possibly to the presence of a former valley that was covered up.

In order to determine the baseline, a geoelectric profile was conducted on the E-W axis (PI. 4); in this case the investigated depth was $20 \mathrm{~m}$. Data processing revealed an average baseline depth of $8 \mathrm{~m}$. This section revealed the presence of a covered valley around $m$ 25-40. A map of the electric field distribution in the area was made based on spontaneous potential measurements (PI. 2/2). An increase of the electric field was recorded from the North to the South. We made this map because the electric field distribution might also provide useful information.
Eng. Florian Rădulescu

S.C. Intel 91 SRL rflorin.geo@gmail.com 



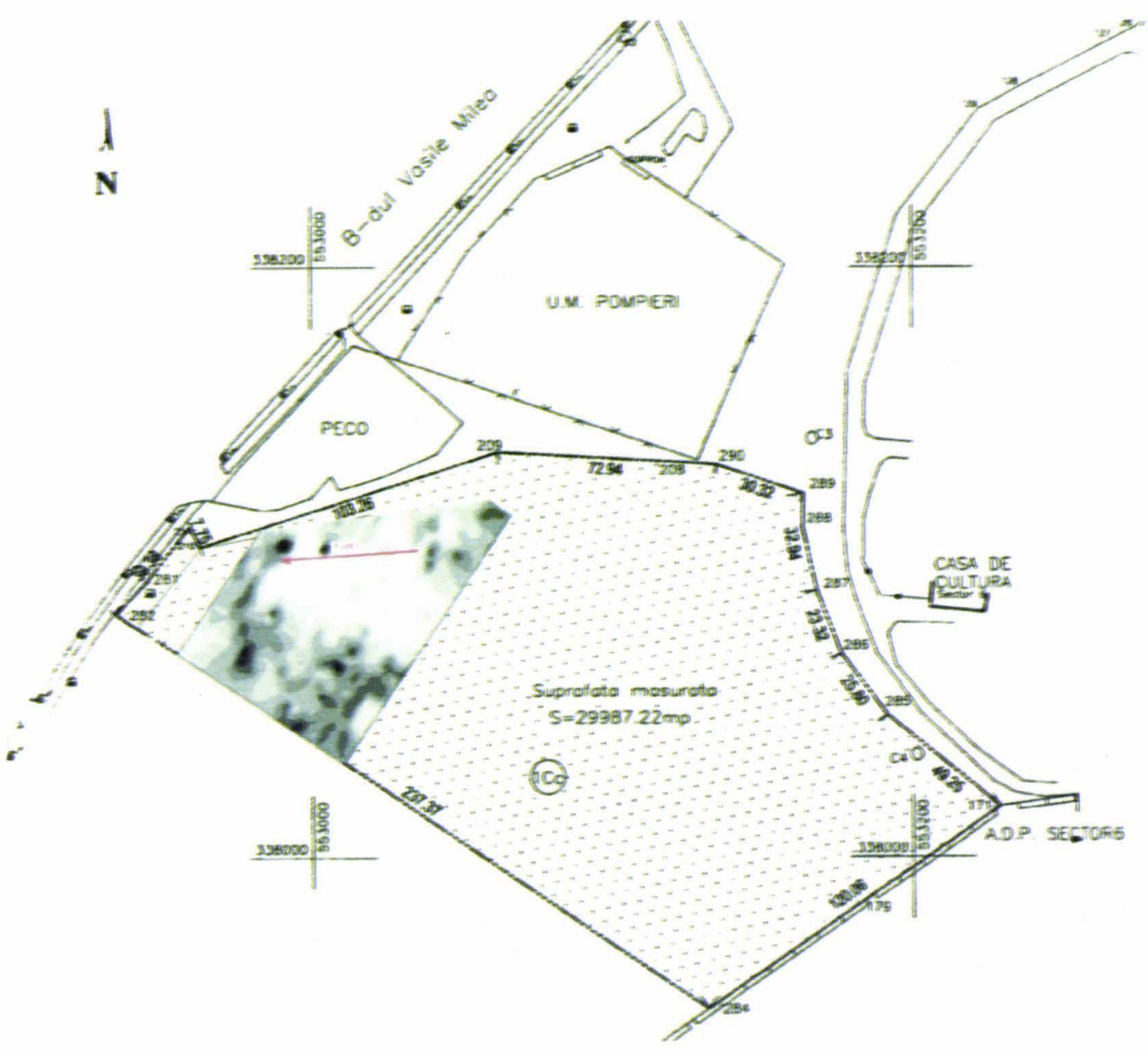

PI. 1 - Annex. 

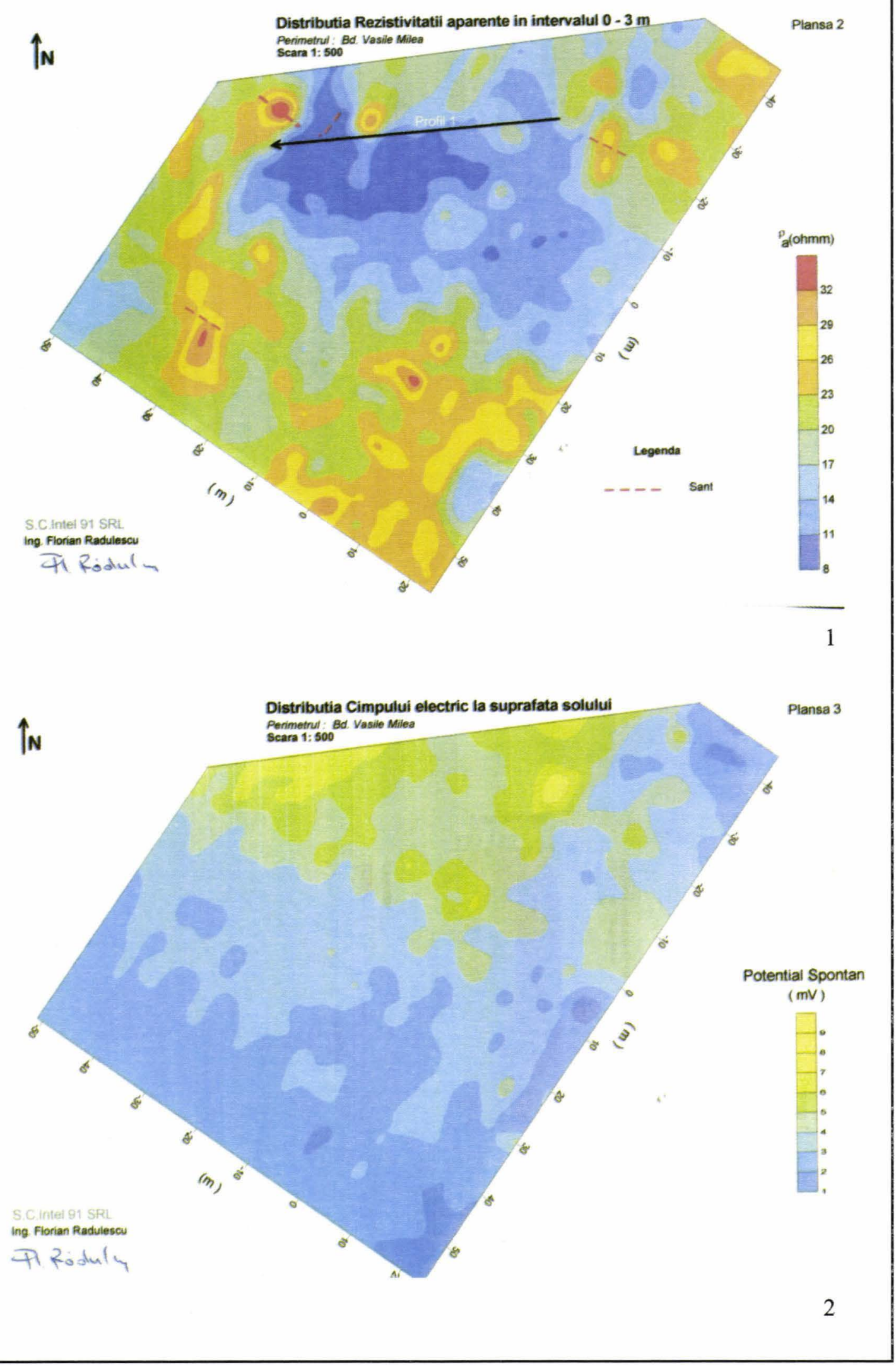

PI. 2 - Annex. 


\section{Pseudosectiune Geoelectrica}

Profil 1 Bd. Vasile Milea

Scara 1: 500

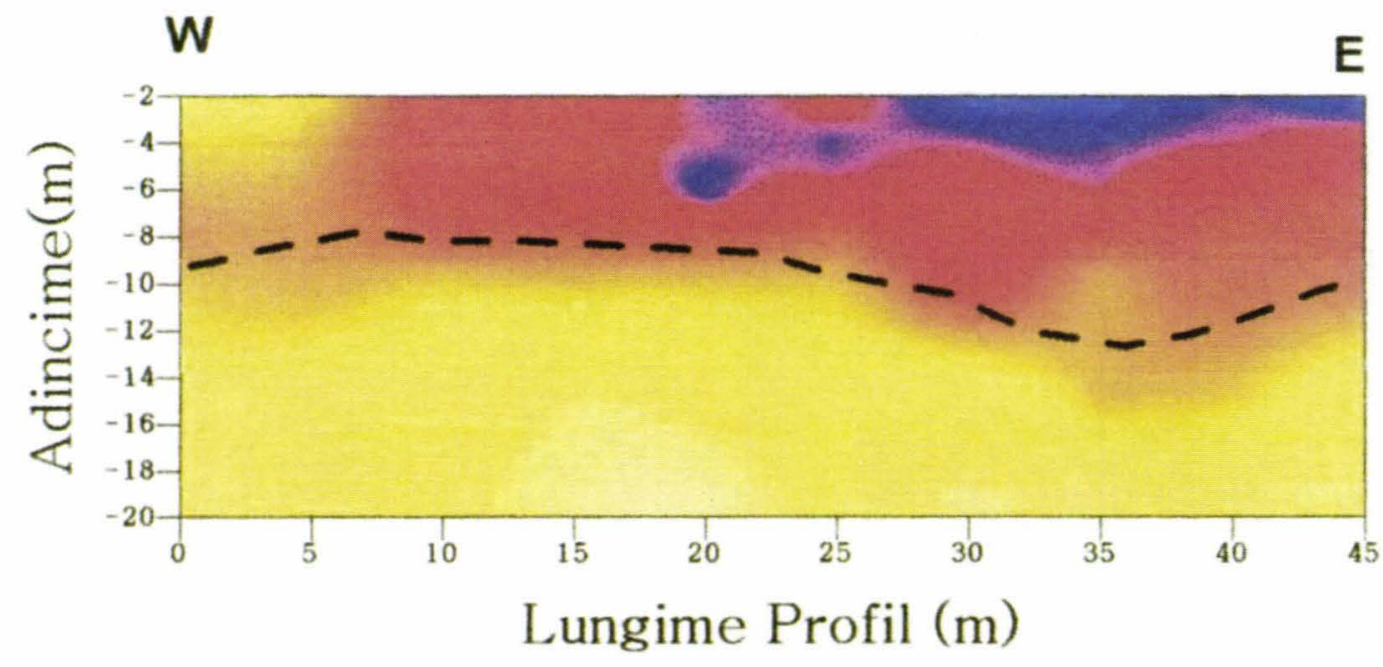

\section{Legenda}

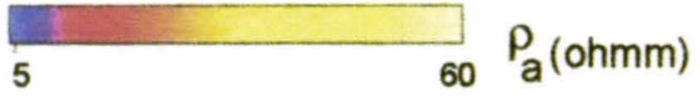

ح Limita umplutura - roca de baza

Pl. 3 - Annex. 
